\title{
Changes in Community Composition of Tropical Evergreen Forests during Succession in Ta Dung National Park, Central Highlands of Vietnam
}

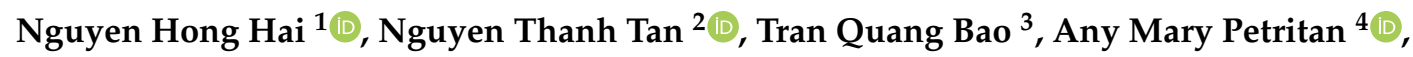 \\ Trinh Hien Mai ${ }^{5}$, Cao Thi Thu Hien ${ }^{1}$, Pham The Anh ${ }^{1}$, Vu Tien Hung ${ }^{1}$ and \\ Ion Catalin Petritan $6, *$ (D) \\ 1 Department of Forest Inventory and Planning, Faculty of Silviculture, Vietnam National University of \\ Forestry, Hanoi 08424, Vietnam; hainh@vnuf.edu.vn (N.H.H.); caohien7983@gmail.com (C.T.T.H.); \\ keodtra@gmail.com (P.T.A.); hungvt@vnuf.edu.vn (V.T.H.) \\ 2 Faculty of Agriculture and Forestry, Tay Nguyen University, Daklak 084262, Vietnam; nttan@ttn.edu.vn \\ 3 Faculty of Forest Resources \& Environmental Management, Vietnam National University of Forestry, \\ Hanoi 08424, Vietnam; baofuv@vnuf.edu.vn \\ 4 National Institute for Research-Development in Forestry 'Marin Dracea', Eroilor 128, \\ 077190 Voluntari, Romania; apetritan@gmail.com \\ 5 College of Wood Industry and Interior Design, Vietnam National University of Forestry, \\ Hanoi 08424, Vietnam; maith@vnuf.edu.vn \\ 6 Faculty of Silviculture and Forest Engineering, Transilvania University of Brașov, Sirul Beethoven 1, \\ 500123 Brasov, Romania \\ * Correspondence: petritan@unitbv.ro
}

Received: 31 October 2020; Accepted: 14 December 2020; Published: 18 December 2020

\begin{abstract}
Degradation of tropical forests is a major driver of the global extinction crisis. A key question is understanding the role of evolution history during forest succession in the context of forest restoration for maintaining ecosystem function and stability. This study was conducted in a fragmented forest landscape in the central highlands of Vietnam. We sampled living trees with diameters at breast height of $\geq 6.0 \mathrm{~cm}$ in nineteen 0.25 ha plots to evaluate forest community structure changes over two early successional stages ( $<10$ years and 10-20 years old) after abandonment and old-growth. We used both statistically metric and nonmetric analyses to examine correlations of community composition during successional stages and along elevational gradients. We found that (i) significant differences existed in the structural compositions between early successional forests and old-growth forests, but did not exist within early successional forests; (ii) the phylogenetic structure shifted from overdispersion to clustering with increasing successional ages; and (iii) above-ground biomass (AGB), representing ecosystem functioning, significantly increased from early-to-late successional stages, but did not correlate with phylogenetic diversity or elevation. Our results revealed that the forest community structure was strongly affected by degradation, particularly AGB and phylogenetic structure. These findings have clear implications for sustaining biodiversity persistence and ecosystem functioning in human-modified landscapes in the study region.
\end{abstract}

Keywords: above-ground biomass; biodiversity; phylogenetic diversity; community assembly; tropical rain forest

\section{Introduction}

Degraded tropical forests due to anthropogenic disturbance are rapidly expanding in the tropics at alarming rates [1,2]. The conversion of tropical forest to monocultural plantations and agricultural 
lands led to mosaic landscapes with various spatial arrangements of tropical evergreen forests of widely varying ages [3]. Considering that forest resilience in maintaining its function and structure is associated with history, evolutionary pressures, and previous extinction, conservation actions should target entire communities, rather than species [4]. Previous studies on forest succession focused on changes in phylogenetic structure and dispersion during succession [3,5-7], while the ecological theory assumes that diversity is positively correlated with productivity when diversity increases niche complementarity, for example, complementary resource use [8]. Few studies quantified the relationship between biodiversity and ecosystem functions (e.g., phylogenetic diversity and forest productivity) during successional process in tropical forests $[3,6,8]$. Expectedly, this approach allows scientists to better understand community assembly by considering the long-term evolutional history of coexisting species [9].

Phylogenetic diversity is assumed to be a good predictor of community stability in biomass productivity throughout space and time as it contains more information about species complementarity, in which a more diverse plant community is able to use resources more completely, thereby, increasing productivity [10-13]. In the tropical forests of Costa Rica, Lasky et al. [8] found a strong correlation between phylogenetic diversity and above-ground biomass (AGB) during the early stages of forest succession. Across geographical regions in the United States, Potter and Woodall [14] reported that phylogenetic diversity was significantly associated with AGB, but weakened with both increasing site productivity and live tree stocking. However, in a subtropical forest of South China, Ouyang et al. [6] found no significant effect of species and phylogenetic diversity on forest biomass in any phase (early, mid, or late) of forest succession. In addition, Rozendaal and Chazdon [15] stated that, depending on the interactions between tree mortality and growth, biomass dynamics were largely regulated by tree growth in early succession and by both in later succession.

The relationship between phylogenetic diversity and forest ecosystem function is simultaneously influenced by many factors, such as disturbance, edaphic and topographic heterogeneity, and speciation [6,16-18]. Phylogenetic clustering suggests abiotic factors drive community assembly processes leading more closely related species to coexist, which in turn, tend to share similar niches, phenotypes in a particular environment, and sensitivities to disturbance [19,20]. Phylogenetic overdispersion, on the other hand, is assumed to dominate later successional stages because of competitive exclusion governing species establishment $[3,21,22]$ as a result of biotic processes, such as species interaction, dispersal and speciation.

Habitat filtering (sunlight, temperature, soil types, topography) plays an important role in selecting species during colonization [3,21]. In addition, Mi et al. [23] found a dominance of stochastic processes with significant interactions between the environment and disturbance over succession, concluding that post-disturbance restoration may be largely unpredictable and difficult to control in subtropical forests. Among abiotic factors, elevation is assumed to have a significant impact on the vegetation structure of most mountain ranges in the world, particularly species diversity, which varies largely depending on the interaction between plant communities, species, and environmental factors [24]. In the tropical forests of Southeast Asia, Satdichanh et al. [3] found a strong correlation between soil fertility and community structure in the early successional stages, with significant elevation associated with above-ground biomass only in forests younger than 100 years. In the mountainous region of Veracruz, up to $3500 \mathrm{~m}$ a.s.1, Mexico, Monge-González et al. [25] found a correlation between tree diversity and community composition along elevational gradients of disturbed forests.

To better understand the change in forest biodiversity and ecosystem functioning, over time, herein, we study the relationship between evolutionary history (phylogenetic diversity and community structure) and forest productivity (e.g., volume and above ground biomass) through different successional forest phases in a mosaic landscape in the central highlands of Vietnam (Figure 1). The present paper uses data from 19 plots from tropical evergreen forests covering three successional stages (early, early-mid, and old-growth), addressing the following questions: (1) How do community structure and phylogenetic diversity change over different successional forest phases? and (2) Do 
taxonomic and phylogenetic diversity correlate with forest productivity and elevation during forest succession?

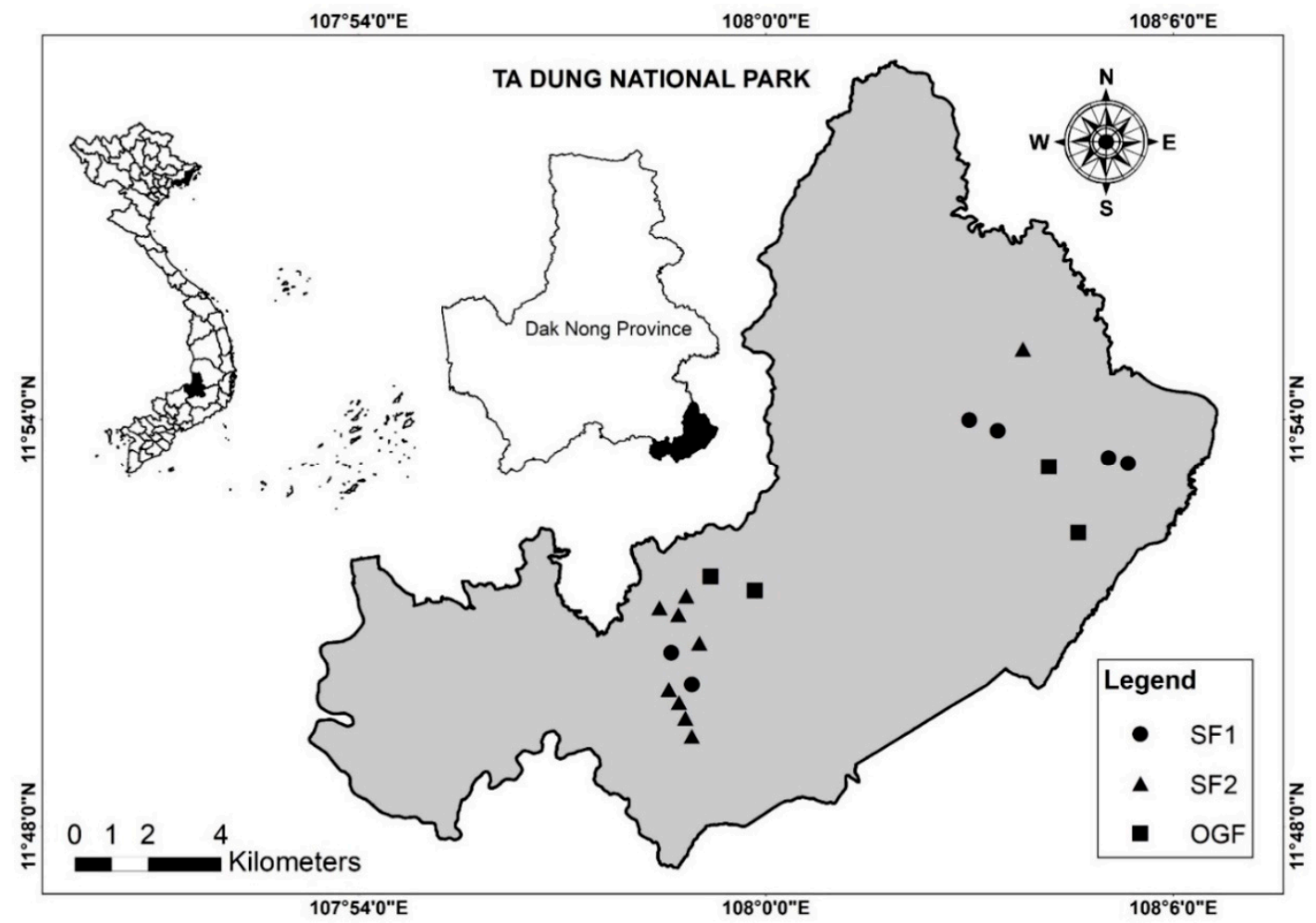

Figure 1. Map of Ta Dung National Park and study plots. Circles are secondary forest plots $<10$ years old (SF1), triangles are secondary forest plots 10-20 years old (SF2), and squares are old-growth forest plots (OGF).

\section{Materials and Methods}

\subsection{Study Site and Data Collection}

The study was conducted at Ta Dung National Park, located in the central highlands of Vietnam (Figure 1). In 2013, The National Park was established in order to maintain high forest protection from human disturbance. Before that time, this region was disturbed by local people in easy access areas, for example, areas close to main roads, local villages, or areas at low elevation, for timber collection or crop plantation. The climate is strongly affected by the seasonal climate, with about $90 \%$ of total precipitation falling from April to November and the dry season lasting from December to March. The average annual rainfall is about $2513 \mathrm{~mm}$ and the annual mean humidity is $84 \%$. The mean annual temperature is $22.5^{\circ} \mathrm{C}$, while the lowest temperature is $14{ }^{\circ} \mathrm{C}$ in December and the highest temperature is $35^{\circ} \mathrm{C}$ in April.

In this study, we classified forest successional stages according to plot land use and disturbance history. The successional stages used were according to secondary forest since abandonment; (a) <10 years old (SF1, early); and (b) 10-20 years old (SF2, early-mid), recovering after illegal logging or slash-and-burn for annual crop plantation, thereby lacking large-diameter trees; and (c) old-growth forest (OGF), a primary forest with tall, large-diameter trees without visible signs of recent human disturbance. The successional stage was assigned at the plot level with help by staff from the National Park.

During 2019-2020, we established 19 plots of 0.25 ha $(50 \times 50 \mathrm{~m})$ each, including six plots in SF1, nine plots in SF2, and four plots in OGF. All live trees with diameters at breast height (dbh) of $\geq 6.0 \mathrm{~cm}$ were recorded in terms of their characteristics (species, dbh, and total tree height). The location and elevation of each study plot were recorded using the GPS Garmin 60s (Garmin Coporation, Taiwan). 


\subsection{Data Analysis}

\subsubsection{Community Diversity and Structure}

Above-ground biomass (AGB) was estimated according to the allometric equation obtained by Chave et al. [26] for pantropical forest stands as,

$$
\mathrm{AGB}=0.0673 \times\left(\mathrm{D}^{2} \times \mathrm{H} \times \rho\right)^{0.976}
$$

where $\mathrm{D}$ is $\mathrm{dbh}(\mathrm{cm}), \mathrm{H}$ is total height $(\mathrm{m})$, and $\rho$ is the wood-specific density $\left(\mathrm{g} / \mathrm{cm}^{3}\right)$. We obtained the wood-specific density $\rho$ for the observed species/genera from various sources [27-31]. In cases where a range of wood density values were reported, we used a median value. Where wood density data were unavailable for a species, the average across all species in that genus or mean wood-specific density of that plot was applied (see [32]).

We used five commonly used and ecologically interpretable indices of taxonomic diversity emphasizing different aspects of species diversity [33], namely, species richness (SR), the Shannon's H and Simpson's D indices of entropy, Margalef's richness (Ma), and Fisher's alpha (Fa). Species richness is the number of species found in a plot. Simpson's dominance is weighted toward the abundance of a species combining species richness and evenness. The Shannon index is more sensitive to rarer species, while the Simpson index [34] responds more to abundant species, both representing two points in a spectrum of relative sensitivity to species number versus relative evenness [35]. Fisher's alpha index was calculated for all trees within each plot [36], combining species richness and abundance in a single metric that is relatively independent of sample size and is commonly used in studies of tropical tree diversity (e.g., [37]). Margalef's richness was calculated, including the number of species and the total amount of individuals in a sample [38].

Species diversity indices were calculated separately for each plot in each forest type using the software PAST ver. 3.25 (PAleontological Statistics, https://folk.uio.no/ohammer/past/). The data of the 19 plots were pooled to model the dbh height curves for all tree individuals, which were fitted best using the equation of Prodan [39].

\subsubsection{Phylogenetic Diversity and Structure}

We used a phylogenetic mega-tree approach to construct separate family level phylogenetic trees to study forest communities. All tree species names were standardized following taxonomic name resolution service ver. 4.0 [40] at http://nrs.iplantcollaborative.org. We then assembled species lists into phylogenies using the phylomatic and the maximum resolved super-tree of Angiosperm Phylogeny Group (APG) IV (R20160415.new, [41]) at http://phylodiversity.net/phylomatic/. To evaluate the phylogenetic structure of tree communities, we used the phylogenetic metrics mean phylogenetic distance (MPD), net related index (NRI), net nearest taxon index (NTI), and mean nearest taxon distance (MNTD) [42], which were calculated using Phylocom software ver. 4.2 [43].

NRI analyzes the degree of phylogenetic relatedness by measuring mean pair-wise phylogenetic distances among constituent species in a community relative to that found in the species pool. Therefore, NRI analyzes phylogenetic structure throughout the phylogeny, while NTI only reflects phylogenetic clumping at the terminal tips of a phylogeny. Using the Phylocom software, the branch lengths of the phylogenies were calibrated using the function Bladj and the node ages were provided by [44], while alpha MPD and NRI were calculated through the function Comstruct by using the "-a" argument to weight species by their abundance. To calculate NRI, we firstly compared the observed values of MPD with those obtained by chance after generating 999 communities from the null model, which maintained the species richness of each sample and randomized species occurrence [45]. NRI and NTI were calculated as following,

$$
\mathrm{NRI}=-\left(\frac{\mathrm{MPD}_{\mathrm{obs}-} \mathrm{MPD}_{\mathrm{rd}}}{\mathrm{sdMPD}_{\mathrm{rd}}}\right) \mathrm{NTI}=-\left(\frac{\mathrm{MNTD}_{\mathrm{obs}-} \mathrm{MNTD}_{\mathrm{rd}}}{\mathrm{sdMNTD}_{\mathrm{rd}}}\right)
$$


where $\mathrm{MPD}_{\mathrm{obs}}$ is the observed mean phylogenetic distance, $\mathrm{MPD}$ rd is the expected mean phylogenetic distance of randomized species assemblages, sdMPD rd $_{\text {is }}$ is the standard deviation of the mean phylogenetic distance of randomized species assemblages, $\mathrm{MNTD}_{\mathrm{obs}}$ is the observed mean nearest taxon distance, $\mathrm{MNTD}_{\mathrm{rd}}$ is the expected mean nearest taxon distance of randomized species assemblages, and sdMNTD $_{\text {rd }}$ is the standard deviation of the mean nearest taxon distance of randomized species assemblages.

Positive NRI and NTI values indicate phylogenetic clustering (i.e., species are more closely related than expected by chance) while negative values indicate phylogenetic overdispersion (i.e., species are more distantly related than expected by chance) [45]. Using Phylocom 4.2, we measured Faith's PD, the sum of branch lengths of the subtending tree of the species present in a community [46], which does not account for species abundance, and Rao's quadratic entropy index Dp, an extension of the Simpson diversity index that incorporates the phylogenetic distance between each pair of species [47].

\subsubsection{Correlation between Community Diversity and Structure}

We examined changes in tree community composition among forest successional stages, such as the stand characteristics (including the number of tree individuals (N) and AGB), species diversity (containing H, 1-D, Ma, and Fa) and phylogenetic structure (including SR, NRI, NTI, MPD, PD, Dp, and MNTD) using the following methods:

(1) Non-metric multidimensional scaling (NMDS) with abundance-based Bray-Curtis dissimilarities (adjustment noshare $=0.1 ; 999$ permutations) was used to test the differences in tree community composition using a nested permutational multivariate analysis of variance (PERMANOVA, 999 permutations). All statistical analyses were performed in R ver. 3.5.1. All tests and ordination plots were computed using the package vegan ver. $2.4-5$ [48]. The variables were fitted onto the NMDS ordinations using the envfit function in the vegan package and goodness of fit and $p$-value were computed 999 times, in order to detect environmental drivers for community dynamics.

(2) Data normality and homogeneity of variances were tested using one-way ANOVA with the Shapiro-Wilk and Levene tests. When the ANOVA indicated a significant difference among forest categories ( $p<0.05, \mathrm{~F}$ test), the differences between means were tested with Scheffe post-hoc test. All statistical analyses were performed using STATISTICA 9.1 (StatSoft, Inc., Tulsa, OK, USA).

\section{Results}

\subsection{Plant Community}

A total of $1198(199.00 \pm 54.38)$ individual trees belonging to 103 species, 79 genera, and 40 families were recorded in six early successional forest plots, less than 10 years old of succession (Table 1 ). At nine early-mid successional forest plots 10-20 years old of succession, 2468 (274.22 \pm 76.53$)$ individual trees of 119 species, 88 genera, and 46 families were measured (Appendix A Table A2). At four old-growth forest plots, a total of 1048 (262.0 \pm 30.61$)$ individuals were counted, belonging to 90 species, 72 genera, and 41 families.

The DBH-height relationship of the three restoration time forest types was well fitted by Prodan (1951), with $\mathrm{R}^{2}$ ranging from 0.52 to 0.76 the strongest correlation at OGF (Figure 2). It was observed that the height curve along a DBH gradient is superior in OGF (Figure 2c) compared to SF1 and SF2 (Figure 2a,b), for a certain DBH value, with the height increment greater than those observed in SF1 and SF2 (Figure 2d). 
Table 1. Structural characteristics and species diversity of the three forest types, (Mean \pm SD).

\begin{tabular}{cccc}
\hline Structural Properties & SF1 & SF2 & OGF \\
\hline Stand structure & & & \\
Density of trees & $199.00 \pm 54.38 \mathrm{a}$ & $274.22 \pm 76.53 \mathrm{a}$ & $262.00 \pm 30.61 \mathrm{a}$ \\
Basal area $\left(\mathrm{m}^{2}\right)$ & $2.24 \pm 1.05 \mathrm{a}$ & $4.29 \pm 2.00 \mathrm{a}$ & $9.49 \pm 1.46 \mathrm{~b}$ \\
Volume $\left(\mathrm{m}^{3}\right)$ & $8.92 \pm 5.26 \mathrm{a}$ & $21.16 \pm 12.79 \mathrm{a}$ & $80.55 \pm 16.99 \mathrm{~b}$ \\
AGB $(\mathrm{Mg})$ & $8.24 \pm 4.71 \mathrm{a}$ & $21.37 \pm 13.53 \mathrm{a}$ & $76.88 \pm 15.82 \mathrm{~b}$ \\
\hline Species diversity & & & \\
Species richness & $35.00 \pm 8.07 \mathrm{a}$ & $41.78 \pm 10.21 \mathrm{ab}$ & $52.75 \pm 1.71 \mathrm{~b}$ \\
Shannon's index & $2.77 \pm 0.51 \mathrm{a}$ & $2.84 \pm 0.52 \mathrm{ab}$ & $3.46 \pm 0.01 \mathrm{~b}$ \\
Margalef's index & $6.47 \pm 1.47 \mathrm{a}$ & $7.28 \pm 1.64 \mathrm{ab}$ & $9.31 \pm 0.46 \mathrm{~b}$ \\
Fisher's alpha & $12.95 \pm 4.26 \mathrm{a}$ & $14.04 \pm 4.35 \mathrm{ab}$ & $20.08 \pm 2.21 \mathrm{~b}$ \\
Simpson's index & $0.87 \pm 0.11 \mathrm{a}$ & $0.86 \pm 0.15 \mathrm{a}$ & $0.95 \pm 0.01 \mathrm{a}$ \\
\hline
\end{tabular}

Values for a parameter followed by different letters differ significantly $(p<0.05)$.
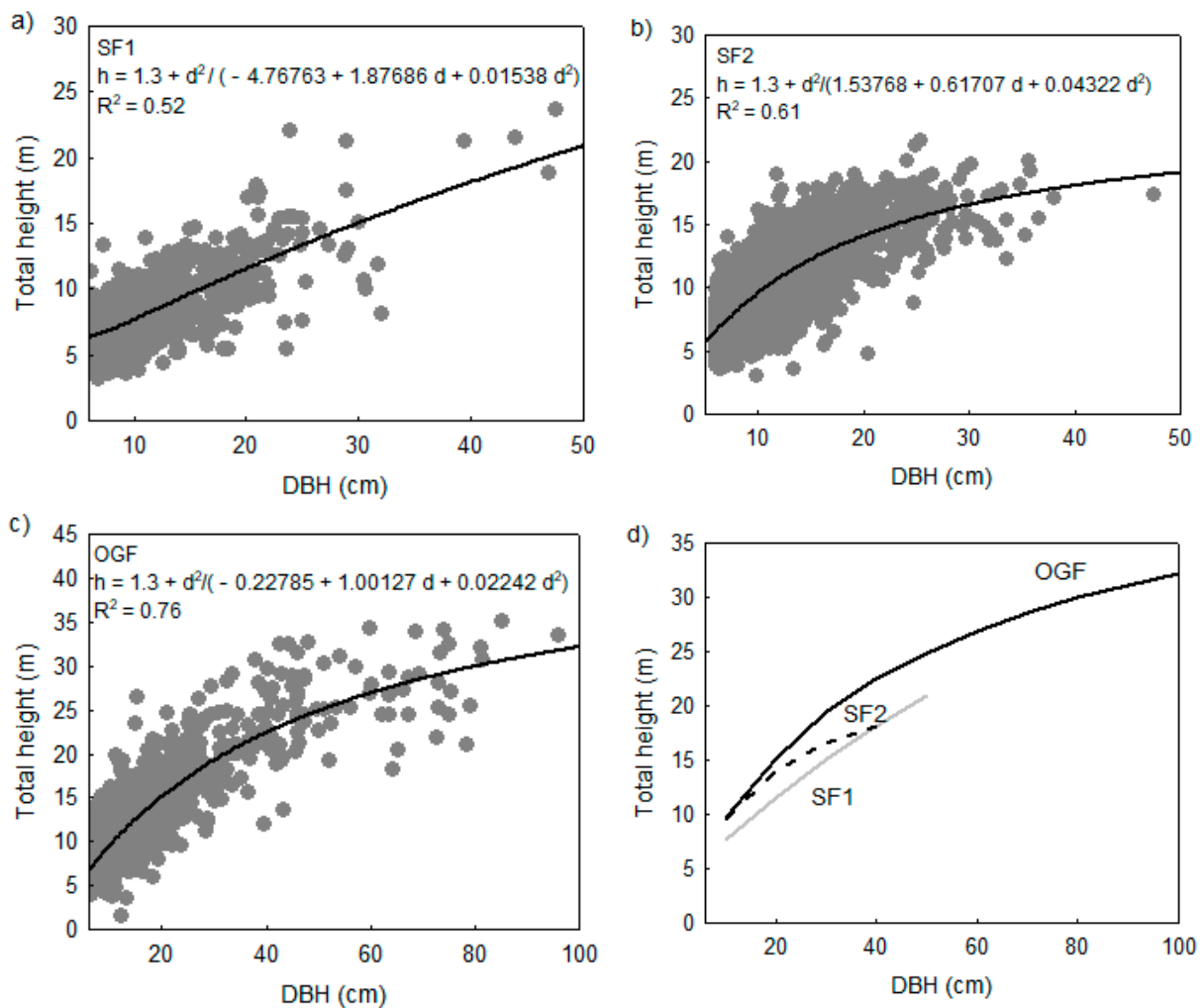

Figure 2. DBH-total height relationship of trees in three forest types.

\subsection{Compositional Pattern of Forest Community}

Significant differences were found between the structural compositions of the forest types, particularly between secondary forests (SF1 and SF2) and old-growth forest (OGF). The PERMANOVA analysis showed statistical significance in the community structure of the three forest types $(\mathrm{F}=2.4651$; $\left.\mathrm{R}^{2}=0.23555, p=0.0011\right)$. However, no significance difference was found in the community structure between the secondary forests SF1 and SF2 $\left(\mathrm{F}=1.0851, \mathrm{R}^{2}=0.07704 ; p=0.3219\right)$.

Fitting the structural community variables with elevation to the NMDS plot, the results showed a significant correlation with $p$-values of $<0.05$ (detail in Appendix A Table A1.), including community diversity and functioning (SR with $\mathrm{R}^{2}=0.44, \mathrm{H}$ with $\mathrm{R}^{2}=0.33,1-\mathrm{D}$ with $\mathrm{R}^{2}=0.5$, Fa with $\mathrm{R}^{2}=0.4$ and AGB with $R^{2}=0.69$ ), phylogenetic structure (MNTD with $R^{2}=0.52$, NTI with $R^{2}=0.63$, Dp with $\mathrm{R}^{2}=0.58$ ), and El with $\mathrm{R}^{2}=0.66$ ) (in red in Figure 3), while N, MPD, NRI, and PD had no correlation, with $p$-values of $>0.05$ (in black in Figure 3). 


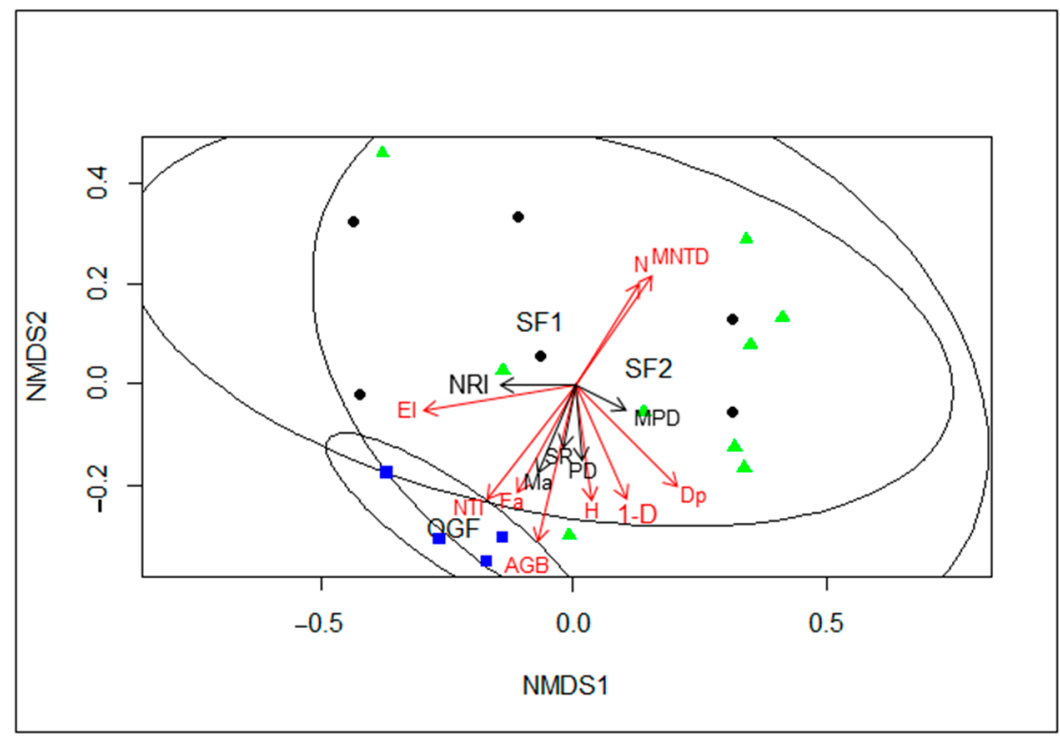

Figure 3. NMDS ordination showing dissimilarities of the compositional structure of the forest types in ellipses: OGF: Old-growth forests (blue squares); SF1:-secondary forests (green triangles); SF2:-secondary forests (black circles) with stress value $=0.09$. Significant variables $(p<0.05)$ are displayed in red arrows and nonsignificant variables $(p>0.05)$ in black arrows. $\mathrm{N}$ : number of individuals, SR: species richness; H: Shannon, (1-D): Simpson, Ma: Margalef, and Fa: Fisher indices; MPD: mean phylogenetic distance, NRI: net related index, NTI: net nearest taxon index, MNTD:-mean nearest taxon distance, PD: phylogenetic diversity; AGB: above-ground biomass, El: elevation.

\subsection{Correlation of Community Composition}

Tree density per plot did not differ significantly among the three restoration type forests (199 individuals per ha in SF1, 274 in SF2 and 262 in OGF) (Table 1). However, in OGF, basal area $\left(9.49 \pm 1.46, \mathrm{~m}^{2}\right)$, volume $\left(80.55 \pm 16.99, \mathrm{~m}^{3}\right)$, and AGB $(76.88 \pm 15.82, \mathrm{Mg})$ per plot were significantly greater than in the other two forest types (Table 1), but these structural properties did not differ between SF1 $\left(2.24 \pm 1.05 \mathrm{~m}^{2} ; 8.92 \pm 5.26 \mathrm{~m}^{3} ; 8.24 \pm 4.71 \mathrm{Mg}\right)$ and SF2 $\left(4.29 \pm 2.00 \mathrm{~m}^{2} ; 21.16 \pm 12.79 \mathrm{~m}^{3}\right.$; $21.37 \pm 13.53 \mathrm{Mg}$ ).

Species richness (number of species) per plot was significantly lower in SF1 (35.00 \pm 8.07$)$ and SF2 $(41.78 \pm 10.21)$ than in OGF $(52.75 \pm 1.71)(p<0.05$, Scheffe post-hoc test, Table 1$)$, but no significant differences were found between SF1 and SF2 ( $p>0.05$, Scheffe post-hoc test). The same pattern was detected also for other diversity indices; Shannon, Margalef, and Fisher alpha indices were significantly greater in OGF compared to the two successional forests (SF1 and SF2), and no significant differences between them were tested. Simpson's index did not differ among forests ( $p>0.05$, Scheffe post-hoc test).

MPD showed the highest value in SF1 $(25.17 \pm 0.90)$ and the lowest in OGF $(21.85 \pm 0.63)$, with significant differences between them (Table 2, details in Appendix A, Figures A1-A3). NRI values were positive in all OGF communities, indicating a clustered phylogenetic structure, but the NRI values of two of six plots (approximately 33\%) in SF1 and four of nine plots (approximately 44\%) in SF2 were negative, indicating phylogenetic over-dispersion. NRI were greater in OGF $(1.44 \pm 0.48)$ than SF1 $(0.502 \pm 0.91)$ and SF2 $(0.02 \pm 0.98)$ but differed in SF2. NTI values were positive in all OGF cases, three cases (approximately 50\%) in SF1, and six cases (approximately 66\%) in SF2, indicating phylogenetic clustering. NTI values were greater significantly in OGF $(1.75 \pm 0.61)$ than in SF1 (0.29 \pm 0.82$)$, but did not differ between SF1 and SF2 $(0.07 \pm 1.62)$. MNTD values were greater significantly in SF1 $(6.64 \pm 1.28)$ than in OGF ( $4.84 \pm 0.53)$, but also did not differ between SF1 and SF2 (6.43 \pm 2.09$)$. PD and Dp indices did not differ between all three successional forest stages $(p>0.05)$. 
Table 2. Phylogenetic structure and diversity of the three forest types (mean $\pm \mathrm{SD}$ ).

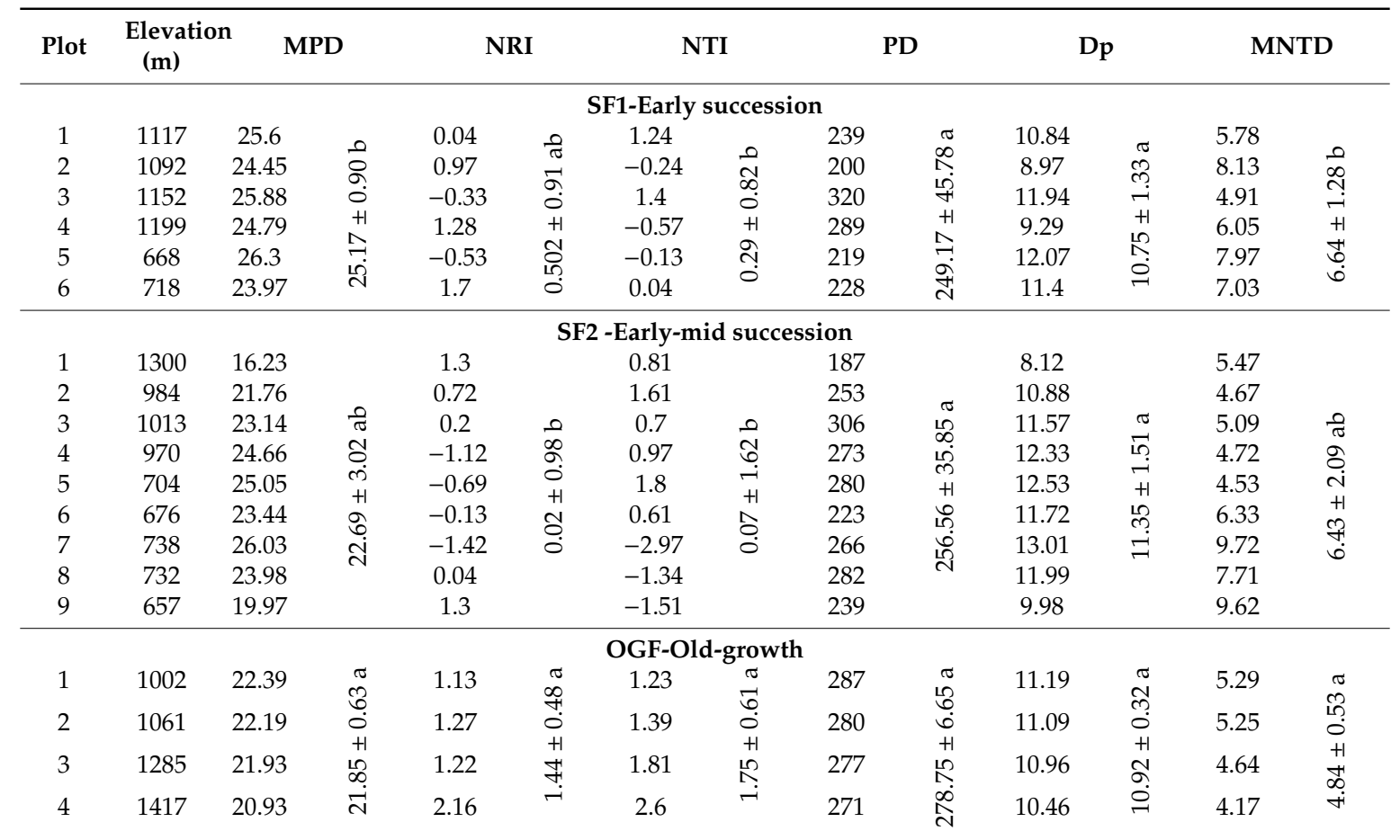

MPD: mean phylogenetic distance, NRI: net related index, NTI: net nearest taxon index, PD: phylogenetic distance, Dp: Rao's quadratic entropy index, MNTD: mean nearest taxon distance. Values for a parameter followed by different letters differ significantly $(p<0.05)$.

\section{Discussion}

Our results showed changes in community structure and phylogenetic diversity over successional forest stages, exhibiting correlations of taxonomic and phylogenetic diversity with forest productivity and elevation. The results showed that the community structure presents changes during forest succession. There was a significant difference between the secondary forests (early and early-mid successions) and old-growth forest in structural composition and phylogeny, while no significant difference within early-successional forests. Community composition and productivity positively correlated with forest succession and elevation.

Our results showed that structural attributes, such as stem density, basal area, volume and AGB were significantly different between the secondary and old-growth forests, but were non-significantly different within the secondary forests. In our study site, AGB increased from 8.24 to $76.88 \mathrm{Mg} / \mathrm{plot}$ (ca. 32.96-307.52 Mg/ha) from secondary forest to old-growth forest types. consistent with previous studies conducted in the central highlands of Vietnam, geographically close to Ta dung National Park [27,30]. Species richness increased from 35 to 52 species from early successional to old-growth forests (Table 1). In a previous study on relationships between species richness and forest productivity, Ouyang et al. [49] found that stand density and age were more important drivers regulating total biomass than species diversity, which has a positive effect on forest productivity in the subtropical forests of China. This effect was consistent with our findings and emphasized the importance of stand density, forest age, and species diversity, whereby, increasing diversity enhances forest productivity and increasing the chance of possessing highly productive species $[50,51]$.

Phylogenetic analyses indicated that old-growth forest contained more closely related species than expected by chance, as shown by phylogenetic clustering and confirmed by positive values of the net-related index and net-nearest taxon indices (Table 2). Moreover, the community structure shifted from overdispersion to clustering in the secondary forest of successional stages $<10$ years old and 10-20 years old, suggesting evidence that species assembly and colonization dominate ecological 
processes, such as niche assembly or facilitation during early forest succession. Our results were contrasted by the findings by Satdichanh et al. [3], conducted in tropical forests of Southeast Asia, who found the phylogenetic community structure shifted from clustering to overdispersion with increasing successional ages from 15-30 years old in secondary forests to old-growth forest. The changes in phylogenetic plant community structure during succession may be regulated by environmental filtering or biotic interactions (deterministic factors such as species, functional, and phylogenetic turnover) or stochastic factors $[3,23]$. Throughout successional stages, species co-occurring within sites are functionally clustered indicates that community assembly is deterministic with respect to species traits [22]. Taxonomic and phylogenetic diversities showed no significant differences (Tables 1 and 2), indicating that these evidences mainly reflect colonization and closely related species [22], which remained during succession in our forest types. Hence, we conclude that as forest succession proceeds, species assembly possesses relative importance, rather than competitive exclusion in our study site.

Recent studies argued the relative importance of phylogenetic and taxonomic diversity in promoting ecosystem stability and community biomass productivity [12,52-55]. For instance, Yuan et al. [55] and Venail et al. [12] reported that phylogenetic diversity does not predict ecosystem functioning, for instance species richness and phylogenetic diversity, while Larkin et al. [53] agreed that phylogenetic diversity provides good information for management and restoration interventions. In this study, phylogenetic and taxonomic diversity were not significantly different between early successional ages, suggesting a failure in detecting phylogenetic diversity as a predictor for ecosystem function. Previous studies $[3,11,13,56]$ argued that this failure may be caused by inappropriate study design when considering the species pool, experimental design, and analyses, such as using inappropriate phylogenies, skewed distributions of phylogenetic distances or the absence of sufficient niche space in experimental and observational venues [57].

Previous studies reported that forest biomass decreases with decreasing elevation [58-60]. In our study, the NMDS analyses showed that elevation significantly correlated with community attributes (e.g., species diversity and above-ground biomass) and phylogenetic structure (NTI and Dp) with $p$-values of $<0.05$ (Appendix A Table A1), particularly in old-growth forest. These findings were consistent with other studies conducted in Southeast Asian forests (e.g., [3,61]. In a tropical forest of Hainan Island, China, Zhu et al. [24] found a community composition, such as tree abundance, species richness, and phylogenetic diversity increased up to $700 \mathrm{~m}$ a.s.l and decreased at the highest elevations of $1175 \mathrm{~m}$, while our results were analyzed up to elevation of $1417 \mathrm{~m}$. Regionally, in Southeast Asia, Culmsee et al. [60] found opposite trends of taxonomic richness and phylogenetic diversity in Malesian mountain forests at elevations from 650 to $3080 \mathrm{~m}$ a.s.l.

\section{Conclusions}

We used a variety of techniques to understand community structure and phylogenetic diversity of trees in Ta Dung National Park, Vietnam. Our study showed variations in phylogenetic diversity and community structure, changing over successional stages of tropical species-rich forests. The results demonstrated the complexity and variability in forest succession of tropical rain forest. From youngto old-growth forests, the structural compositions differed between early successions and old-growth forests, but not within early successional forests. The phylogenetic structure shifted from overdispersion to clustering, while the above-ground biomass-AGB increased, but was not associated with phylogenetic diversity or elevation. Our results suggest that biodiversity and stand structure should be considered simultaneously to evaluate and monitor the effectiveness of management practices in order to recover disturbed forest stands. Long-term experimental and comprehensive studies considering key biotic (including community properties) and abiotic (such as elevation, aspect, and slope) factors should be carried out in order to observe the changes during forest succession for the maintenance of forest biodiversity and function. 
Author Contributions: N.H.H., C.T.T.H., P.T.A., V.T.H. and N.T.T. conceived and designed the experiment and collected the data; N.H.H., N.T.T., T.Q.B. and I.C.P. analyzed the data; N.H.H., N.T.T., T.Q.B., A.M.P., T.H.M. and I.C.P. wrote the paper. All authors have read and agreed to the published version of the manuscript.

Funding: This research was funded by Vietnam National Foundation for Science and Technology DevelopmentNAFOSTED (106.06-2019.307) and Ministry of Education and Training of Vietnam-MOET (B2019-TTN 02).

Acknowledgments: We are grateful for constructive comments and suggestions of two anonymous reviewers and subject editor, which were really helpful to improve the manuscript.

Conflicts of Interest: The authors declare no conflict of interest.

\section{Appendix A}

Table A1. NMDS ordination of the compositional structure of three forest types.

\begin{tabular}{ccccc}
\hline & NMDS1 & NMDS2 & $\mathbf{r}^{\mathbf{2}}$ & $\operatorname{Pr}(>\boldsymbol{r})$ \\
\hline El & -0.99225 & -0.12427 & 0.6608 & 0.002 \\
N & 0.50871 & 0.86094 & 0.4423 & 0.009 \\
AGB & -0.32277 & -0.94648 & 0.6935 & 0.001 \\
X1.D & 0.41065 & -0.91179 & 0.5036 & 0.003 \\
H & 0.17959 & -0.98374 & 0.3267 & 0.041 \\
Fa & -0.45491 & -0.89054 & 0.4011 & 0.018 \\
Ma & -0.39278 & -0.91963 & 0.2733 & 0.074 \\
SR & -0.28326 & -0.95904 & 0.1225 & 0.331 \\
MPD & 0.9323 & -0.36169 & 0.0882 & 0.5 \\
NRI & -0.9995 & -0.03152 & 0.1574 & 0.275 \\
NTI & -0.54346 & -0.83943 & 0.6318 & 0.001 \\
PD & 0.1418 & -0.9899 & 0.1624 & 0.233 \\
Dp & 0.6978 & -0.71629 & 0.5767 & 0.003 \\
MNTD & 0.56364 & 0.82602 & 0.5168 & 0.008 \\
\hline
\end{tabular}

NMDS1 and NMDS2: Non-metric multidimensional scaling axes, r: proportion, Pr: significance. 


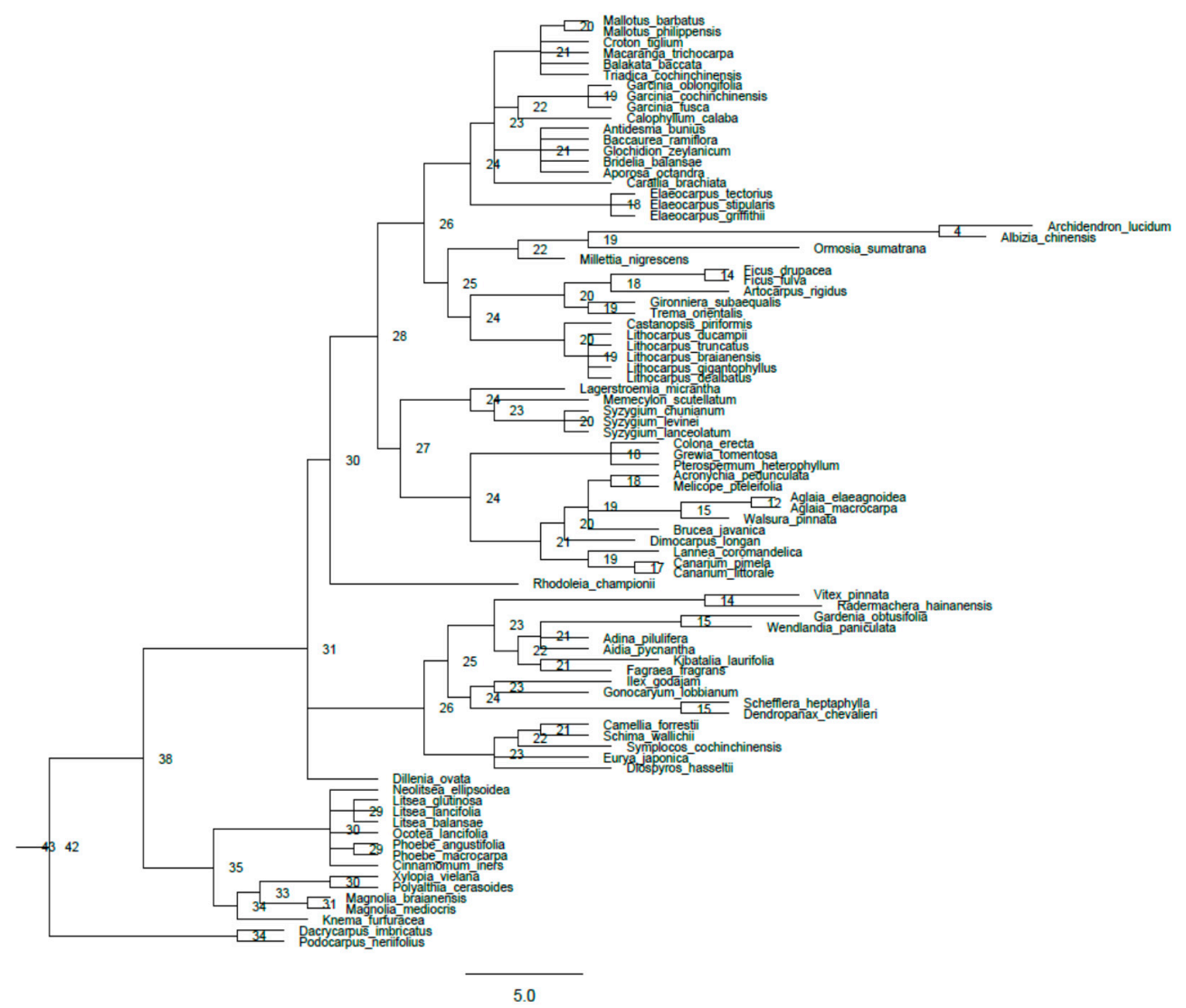

Figure A1. Phylogenetic tree of OGF. 


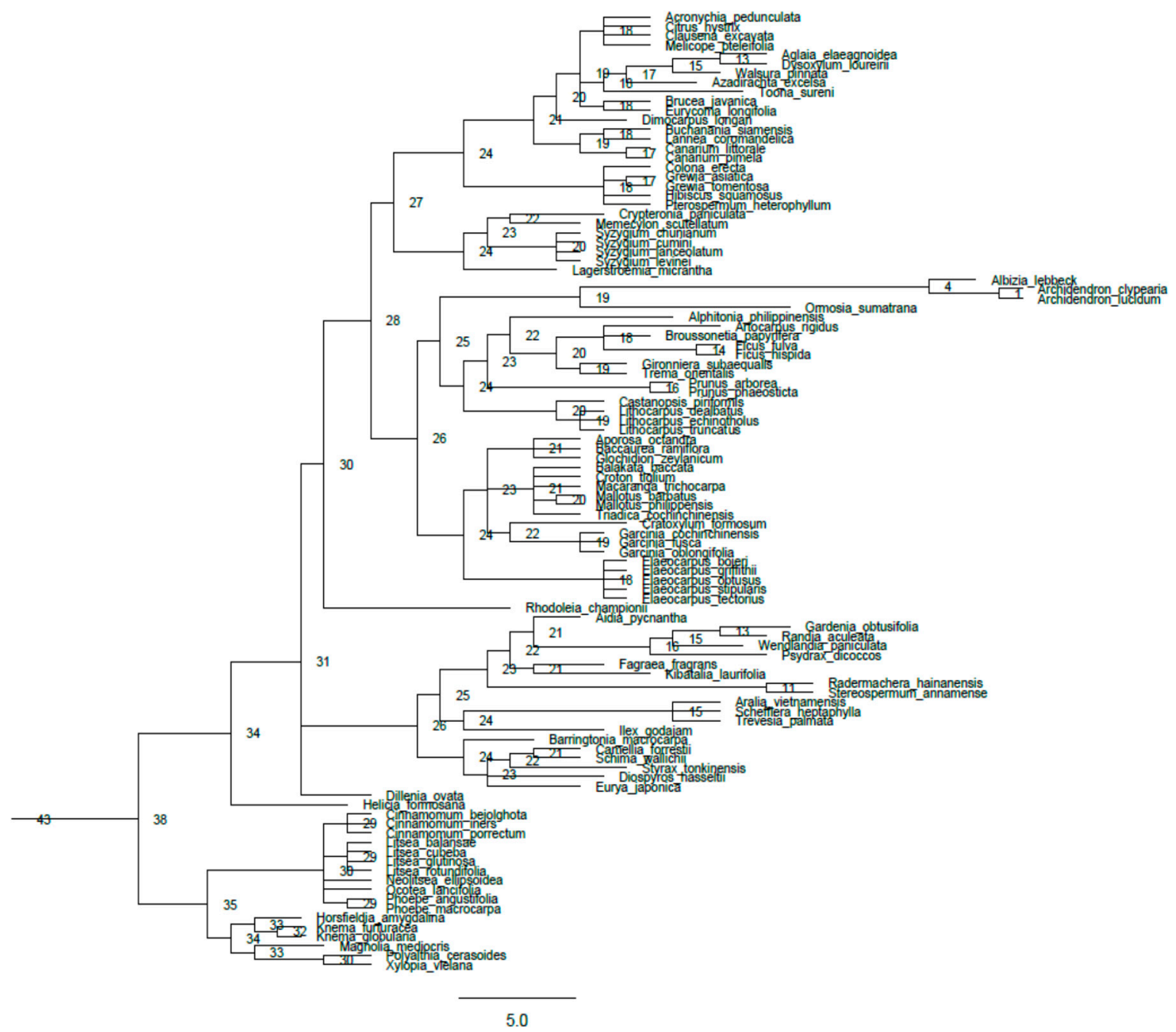

Figure A2. Phylogenetic tree of SF1. 


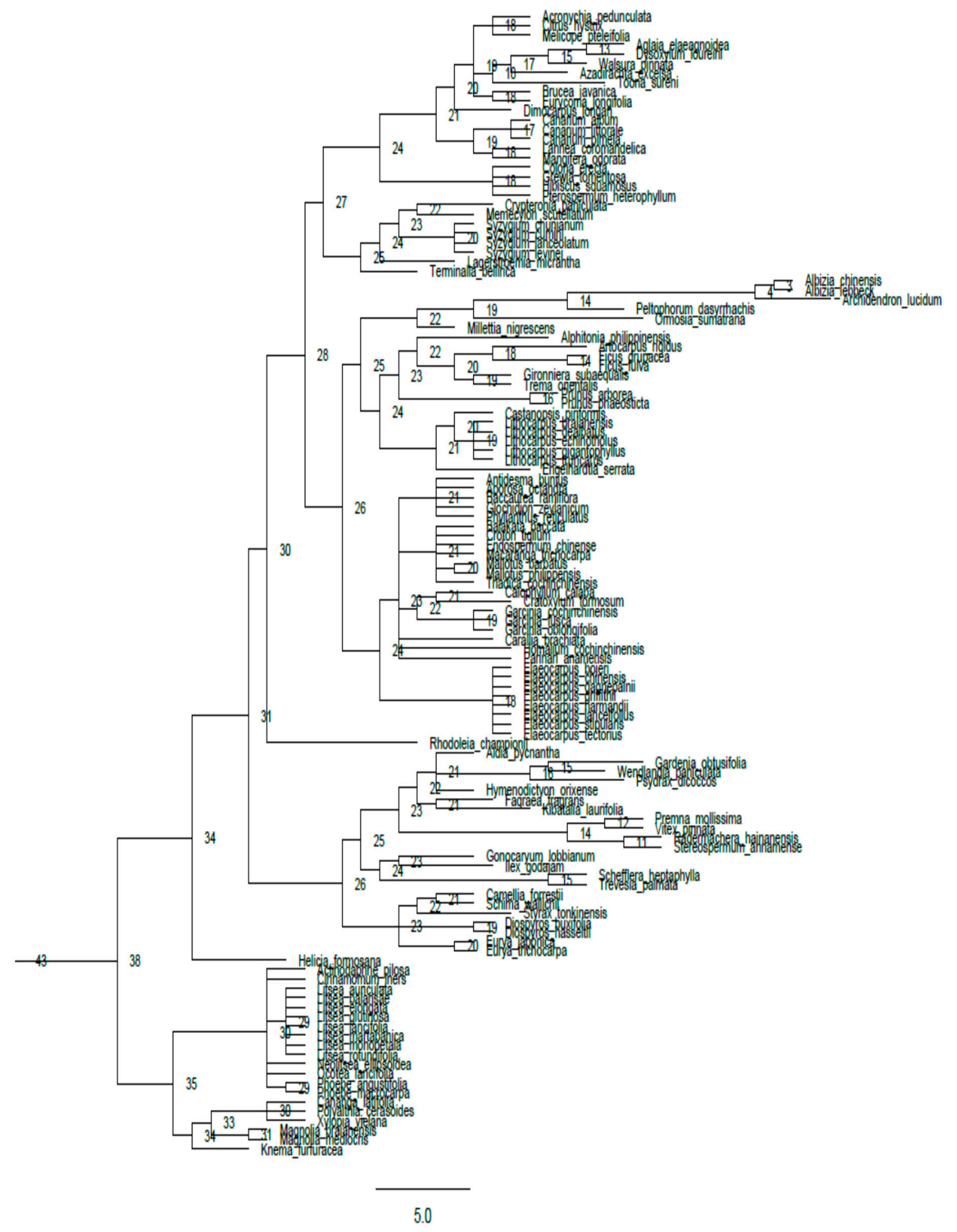

Figure A3. Phylogenetic tree of SF2. 
Table A2. Number of Species Individuals Per Study Plot.

\begin{tabular}{|c|c|c|c|c|c|c|c|c|c|c|c|c|c|c|c|c|c|c|c|c|c|}
\hline \multirow{2}{*}{ No } & \multirow{2}{*}{ Species } & \multirow{2}{*}{ Family } & \multicolumn{6}{|c|}{ SF1 Plots } & \multicolumn{9}{|c|}{ SF2 Plots } & \multicolumn{4}{|c|}{ OGF Plots } \\
\hline & & & 1 & 2 & 3 & 4 & 5 & 6 & 1 & 2 & 3 & 4 & 5 & 6 & 7 & 8 & 9 & 1 & 2 & 3 & 4 \\
\hline 1 & Acronychia pedunculata (L.) Miq. & Rutaceae & 20 & 2 & 12 & & 1 & 5 & 1 & 41 & 62 & 4 & 6 & 6 & 4 & 11 & 3 & 1 & 2 & 9 & 7 \\
\hline 2 & Actinodaphne pilosa (Lour.) Merr. & Lauraceae & & & & & & & & & 3 & & & & & & & & & & \\
\hline 3 & $\begin{array}{l}\text { Aglaia elaeagnoidea } \\
\text { (A. Juss.) Benth. }\end{array}$ & Meliaceae & 1 & & & & & & & 4 & 4 & 7 & & & & & & 2 & & 5 & 1 \\
\hline 4 & Aidia pycnantha (Drake) Tirveng. & Rubiaceae & & & & & & & & & & & 2 & & & & & 1 & 1 & & 1 \\
\hline 5 & Albizia chinensis (Osbeck) Merr. & Fabaceae & & & & & & & & & 1 & 9 & & & & & & 1 & & & 2 \\
\hline 6 & Albizia lebbeck (L.) Benth. & Fabaceae & & 1 & 5 & & & 1 & & & 6 & 37 & 5 & & & & & & & & \\
\hline 7 & Alphitonia philippinensis Braid & Rhamnaceae & & 1 & 3 & & & 1 & & & & 1 & & & & & & & & & \\
\hline 8 & Alstonia scholaris (L.) R. Br. & Apocynaceae & & & 1 & & 1 & & & & 1 & 2 & & & & & & & & & \\
\hline 9 & Antidesma bunius (L.) Spreng. & Phyllanthaceae & & & & & & & & & 2 & & & & & & & & 1 & & \\
\hline 10 & $\begin{array}{l}\text { Aporosa octandra (Buch.-Ham. } \\
\text { ex D. Don) Vickery }\end{array}$ & Phyllanthaceae & & & & & 21 & 1 & & & 38 & 1 & 2 & 3 & 3 & 10 & 7 & 1 & 3 & 1 & \\
\hline 11 & Aralia vietnamensis $\mathrm{Ha}$ & Araliaceae & 1 & & 1 & 1 & & & & & & & & & & & & & & & \\
\hline 12 & $\begin{array}{c}\text { Archidendron clypearia (Jack) } \\
\text { I.C.Nielsen }\end{array}$ & Fabaceae & & 1 & & & & & & & & & & & & & & & & & \\
\hline 13 & $\begin{array}{l}\text { Archidendron lucidum (Benth.) } \\
\text { I.C.Nielsen }\end{array}$ & Fabaceae & & & & & 6 & 1 & & 10 & 16 & 3 & 9 & 4 & 13 & 3 & 3 & & 2 & 2 & 1 \\
\hline 14 & Artocarpus rigidus Blume & Moraceae & 1 & 1 & 1 & 4 & 1 & & & 2 & 1 & 3 & 1 & & & 1 & & & & 1 & 1 \\
\hline 15 & Azadirachta excelsa (Jack) Jacobs & Meliaceae & & 2 & 10 & 1 & & & & & 4 & & & & & & & & 3 & 1 & \\
\hline 16 & Baccaurea ramiflora Lour. & Phyllanthaceae & 27 & 2 & 2 & 5 & & 1 & 5 & 8 & 7 & 8 & 7 & 1 & 7 & 9 & 7 & 21 & 1 & & 7 \\
\hline 17 & Balakata baccata (Roxb.) Esser & Euphorbiaceae & 8 & 6 & 3 & 3 & & 1 & 1 & & & 87 & & & & & & 1 & & & \\
\hline 18 & Barringtonia macrocarpa Hassk. & Lecythidaceae & & 3 & & & & & & & & & & & & & & & & & \\
\hline 19 & $\begin{array}{l}\text { Broussonetia papyrifera (L.) } \\
\text { L'HÃ@Cr. ex Vent. }\end{array}$ & Moraceae & & 1 & 1 & & & & & & & & & & & & & & & & \\
\hline 20 & Brucea javanica (L.) Merr. & Simaroubaceae & & & & 16 & & & & & & 1 & & & & & & 1 & 1 & & \\
\hline 21 & Buchanania siamensis Miq. & Anacardiaceae & & & & & & 1 & & & & & & & & & & & & & \\
\hline 22 & Calophyllum calaba L. & Calophyllaceae & & & & & & & 1 & & & & & & & & & 2 & 2 & 2 & \\
\hline 23 & $\begin{array}{c}\text { Camellia forrestii (Diels) } \\
\text { Cohen-Stuart }\end{array}$ & Theaceae & & & & & 1 & & 1 & 1 & & & 2 & 2 & 3 & 11 & & 2 & 1 & 1 & \\
\hline 24 & $\begin{array}{l}\text { Cananga latifolia (Hook.f. \& } \\
\text { Thomson) Finet \& Gagnep. }\end{array}$ & Annonaceae & & & & & & & & & & & 1 & & & & & & & & \\
\hline 25 & Canarium album (Lour.) DC. & Burseraceae & & & & & & & & & & 1 & & & & 1 & & & & & \\
\hline 26 & Canarium littorale Blume & Burseraceae & 4 & 1 & & 2 & & & & 3 & 1 & 3 & & & 1 & & & 1 & 1 & & \\
\hline 27 & Canarium pimela K.D. Koenig & Burseraceae & 1 & & 2 & 4 & & & & 1 & & & & & & & & 3 & 3 & 3 & \\
\hline 28 & Carallia brachiata (Lour.) Merr. & Rhizophoraceae & & & & & & & & 9 & 2 & & 1 & & & 1 & & & 3 & & \\
\hline
\end{tabular}


Table A2. Cont.

\begin{tabular}{|c|c|c|c|c|c|c|c|c|c|c|c|c|c|c|c|c|c|c|c|c|c|}
\hline \multirow{2}{*}{ No } & \multirow{2}{*}{ Species } & \multirow{2}{*}{ Family } & \multicolumn{6}{|c|}{ SF1 Plots } & \multicolumn{9}{|c|}{ SF2 Plots } & \multicolumn{4}{|c|}{ OGF Plots } \\
\hline & & & 1 & 2 & 3 & 4 & 5 & 6 & 1 & 2 & 3 & 4 & 5 & 6 & 7 & 8 & 9 & 1 & 2 & 3 & 4 \\
\hline 29 & $\begin{array}{l}\text { Castanopsis piriformis } \\
\text { Hickel \& A.Camus }\end{array}$ & Fagaceae & & & 3 & 5 & 3 & & & & 5 & 1 & & 85 & & 20 & 8 & 2 & & & 3 \\
\hline 30 & $\begin{array}{l}\text { Cinnamomum bejolghota } \\
\text { (Buch.-Ham.) Sweet }\end{array}$ & Lauraceae & 1 & & & & & & & & & & & & & & & & & & 1 \\
\hline 31 & $\begin{array}{l}\text { Cinnamomum iners } \\
\text { Reinw. ex Blume }\end{array}$ & Lauraceae & 29 & 3 & 12 & 5 & 1 & 1 & & 21 & 9 & 3 & 5 & 2 & 2 & & & 12 & 19 & 4 & 11 \\
\hline 32 & $\begin{array}{c}\text { Cinnamomum porrectum (Roxb.) } \\
\text { Kosterm. }\end{array}$ & Lauraceae & & & & & & 1 & & & & & & & & & & & & & \\
\hline 33 & Citrus hystrix DC. & Rutaceae & & & 1 & 1 & & & & & & & & & & & 1 & & & & \\
\hline 34 & Clausena excavata Burm. f. & Rutaceae & 4 & 4 & & 6 & 1 & & & & & & & & & & & & & & \\
\hline 35 & Colona erecta (Pierre) Burret & Malvaceae & 1 & 1 & 1 & & 1 & & 1 & 7 & 1 & & 1 & & 2 & 1 & & 6 & 3 & 3 & 6 \\
\hline 36 & $\begin{array}{l}\text { Cratoxylum formosum (Jack) } \\
\text { Benth. \& Hook. f. ex Dyer }\end{array}$ & Hypericaceae & & & & & 4 & 8 & & & 2 & & 26 & 18 & 4 & 17 & 7 & & & & \\
\hline 37 & Croton tiglium $\mathrm{L}$. & Euphorbiaceae & 6 & 1 & 1 & 1 & & & & & 1 & 1 & & & & & & 16 & 16 & 6 & 21 \\
\hline 38 & Crypteronia paniculata Blume & Crypteroniaceae & & & & & 12 & 21 & & & & & 1 & 6 & 2 & & 3 & & & & \\
\hline 39 & $\begin{array}{l}\text { Dillenia ovata Wall. ex Hook.f. } \\
\text { \& Thomson }\end{array}$ & Dilleniaceae & & & & & 1 & 2 & & & & & & & & & & 2 & 10 & 5 & 10 \\
\hline 40 & Dimocarpus longan Lour. & Sapindaceae & 1 & & & & 3 & 6 & & & & 9 & & & 22 & 1 & 3 & 6 & 3 & & \\
\hline 41 & Diospyros buxifolia (Blume) Hiern & Ebenaceae & & & & & & & & 1 & & & & & & & & & & & \\
\hline 42 & Diospyros hasseltii Zoll. & Ebenaceae & 1 & & & & & & 5 & & & 1 & 1 & & & & & & 3 & 3 & \\
\hline 43 & $\begin{array}{c}\text { Dysoxylum loureirii (Pierre) } \\
\text { Pierre ex Laness. }\end{array}$ & Meliaceae & 2 & & 1 & 1 & & & 3 & 2 & & & & & & & & & & & \\
\hline 44 & Elaeocarpus bojeri R.E. Vaughan & Elaeocarpaceae & & & & & & & & & & 1 & 2 & & & & & & & & \\
\hline 45 & $\begin{array}{l}\text { Elaeocarpus chinensis (Gardner \& } \\
\text { Champ.) Hook. f. ex Benth. }\end{array}$ & Elaeocarpaceae & & & & 1 & & & & & & & & & & & & 1 & & & \\
\hline 46 & Elaeocarpus gagnepainii Merr. & Elaeocarpaceae & & & & & & & & 1 & & & & & 1 & & & & & & \\
\hline 47 & $\begin{array}{c}\text { Elaeocarpus griffithii (Wight) } \\
\text { A.Gray }\end{array}$ & Elaeocarpaceae & & & & & & 3 & & & 2 & 4 & 16 & 9 & 6 & 5 & 1 & & 1 & & 2 \\
\hline 48 & Elaeocarpus harmandii Pierre & Elaeocarpaceae & & & & & & & & & & & & & & 1 & & & & & \\
\hline 49 & Elaeocarpus lanceifolius Roxb. & Elaeocarpaceae & & & & & & & & & & 1 & & & & & & & & & \\
\hline 50 & Elaeocarpus obtusus Blume & Elaeocarpaceae & & & & & & & 1 & & & & & & & & & & & & 1 \\
\hline 51 & Elaeocarpus stipularis Blume & Elaeocarpaceae & & & & & & 2 & & 1 & & 1 & 12 & 2 & & 8 & 3 & & & 1 & \\
\hline 52 & Elaeocarpus tectorius Poir. & Elaeocarpaceae & 2 & 1 & 3 & 2 & & & 1 & 29 & 8 & & 3 & 2 & & & & 3 & 7 & 2 & 8 \\
\hline 53 & Endospermum chinense Benth & Euphorbiaceae & & & & & & & & & 1 & & 1 & & & & & & & & \\
\hline 54 & Engelhardtia serrata Blume & Juglandaceae & & & & & & & & & & & 1 & & 1 & & & & & & \\
\hline 55 & Eurya japonica Thunb. & Pentaphylacaceae & & & & & & & & & & & & 1 & 1 & 3 & & 3 & 5 & 2 & \\
\hline
\end{tabular}


Table A2. Cont.

\begin{tabular}{|c|c|c|c|c|c|c|c|c|c|c|c|c|c|c|c|c|c|c|c|c|c|}
\hline \multirow{2}{*}{ No } & \multirow{2}{*}{ Species } & \multirow{2}{*}{ Family } & \multicolumn{6}{|c|}{ SF1 Plots } & \multicolumn{9}{|c|}{ SF2 Plots } & \multicolumn{4}{|c|}{ OGF Plots } \\
\hline & & & 1 & 2 & 3 & 4 & 5 & 6 & 1 & 2 & 3 & 4 & 5 & 6 & 7 & 8 & 9 & 1 & 2 & 3 & 4 \\
\hline 56 & Eurya trichocarpa Korth. & Pentaphylacaceae & & & & & & & & & & & & 4 & 1 & 1 & 3 & & & & \\
\hline 57 & Eurycoma longifolia Jack & Simaroubaceae & & & & & & & & & & 1 & & & & & & & & & \\
\hline 58 & $\begin{array}{c}\text { Fagraea fragrans Roxb. ex } \\
\text { Carey \& Wall. }\end{array}$ & Gentianaceae & & & & & 3 & & & & & & & 18 & 41 & & 1 & & & & 3 \\
\hline 59 & Ficus drupacea Thunb. & Moraceae & & & & & & & 1 & & & & & & & & & 1 & & & \\
\hline 60 & Ficus fulva Reinw. & Moraceae & & & & & & & & 1 & 3 & 30 & & & & & & & 1 & & \\
\hline 61 & Ficus hispida L. f. & Moraceae & & 2 & & & & & & & & & & & & & & & & & \\
\hline 62 & $\begin{array}{l}\text { Garcinia cochinchinensis } \\
\text { (Lour.) Choisy }\end{array}$ & Clusiaceae & & & & 2 & & & 2 & 2 & & & & & & & & 2 & & & 5 \\
\hline 63 & Garcinia fusca Pierre & Clusiaceae & & & & & & & & & & & 6 & 4 & 8 & 12 & & & & 3 & 7 \\
\hline 64 & $\begin{array}{l}\text { Garcinia oblongifolia } \\
\text { Champ. ex Benth. }\end{array}$ & Clusiaceae & 1 & 2 & & & & & & & & 1 & 2 & & & & & 1 & 2 & 8 & 9 \\
\hline 65 & $\begin{array}{l}\text { Gardenia obtusifolia } \\
\text { Roxb. ex Hook.f. }\end{array}$ & Rubiaceae & 3 & 2 & & 2 & & & & 1 & 3 & & & & & & & 2 & & & \\
\hline 66 & Gironniera subaequalis Planch. & Cannabaceae & 5 & & 3 & & & & & 1 & 2 & 8 & & & & & & & 2 & 2 & 8 \\
\hline 67 & $\begin{array}{l}\text { Glochidion zeylanicum } \\
\text { (Gaertn.) A. Juss. }\end{array}$ & Phyllanthaceae & 1 & 5 & 3 & 11 & & 4 & & 4 & 18 & 3 & & & & & & 1 & & & \\
\hline 68 & $\begin{array}{l}\text { Gonocaryum lobbianum } \\
\text { (Miers) Kurz }\end{array}$ & Cardiopteridaceae & & & & & & & 2 & 1 & & & & & & & & & & & 1 \\
\hline 69 & Grewia asiatica L. & Malvaceae & 1 & 3 & & & & & & & & & & & & & & & & & \\
\hline 70 & Grewia tomentosa Juss. & Malvaceae & & & & & & & & & 1 & & & 1 & & & & & 1 & 2 & 1 \\
\hline 71 & Helicia formosana Hemsl. & Proteaceae & & & & & & 10 & & & & & & & 1 & 4 & & & & & \\
\hline 72 & Hibiscus squamosus Hochr. & Malvaceae & 1 & & 1 & & & & & & & & 3 & 1 & & & & & & & \\
\hline 73 & $\begin{array}{l}\text { Homalium cochinchinensis } \\
\text { (Lour.) Druce }\end{array}$ & Salicaceae & & & 1 & & & & & & & 2 & & & & & & & & & \\
\hline 74 & $\begin{array}{l}\text { Horsfieldia amygdalina } \\
\text { (Wall.) Warb. }\end{array}$ & Myristicaceae & & & & & & 1 & & & & & & & & & & & & & \\
\hline 75 & $\begin{array}{l}\text { Hymenodictyon orixense } \\
\text { (Roxb.) Mabb. }\end{array}$ & Rubiaceae & & & & & & & & & & & & 1 & & & & & & & \\
\hline 76 & $\begin{array}{l}\text { Ilex godajam (Colebr. ex Wall.) } \\
\text { Wall. ex Hook. f. }\end{array}$ & Aquifoliaceae & & & & & 1 & 6 & & & & & 1 & & 11 & 1 & & & & 2 & \\
\hline 77 & $\begin{array}{l}\text { Kibatalia laurifolia (Ridl.) } \\
\text { Woodson }\end{array}$ & Apocynaceae & 6 & & & & & & 1 & & & & & & & & & & & 1 & \\
\hline 78 & $\begin{array}{c}\text { Knema furfuracea } \\
\text { (Hook. f. \& Thomson) Warb. }\end{array}$ & Myristicaceae & & & & & 3 & & & 2 & & & 1 & 2 & 1 & 6 & 2 & 1 & & 1 & 1 \\
\hline 79 & Knema globularia (Lam.) Warb. & Myristicaceae & & & & & 1 & & & & & & & & & & & & & & \\
\hline
\end{tabular}


Table A2. Cont.

\begin{tabular}{|c|c|c|c|c|c|c|c|c|c|c|c|c|c|c|c|c|c|c|c|c|c|}
\hline \multirow{2}{*}{ No } & \multirow{2}{*}{ Species } & \multirow{2}{*}{ Family } & \multicolumn{6}{|c|}{ SF1 Plots } & \multicolumn{9}{|c|}{ SF2 Plots } & \multicolumn{4}{|c|}{ OGF Plots } \\
\hline & & & 1 & 2 & 3 & 4 & 5 & 6 & 1 & 2 & 3 & 4 & 5 & 6 & 7 & 8 & 9 & 1 & 2 & 3 & 4 \\
\hline 80 & Lagerstroemia micrantha Merr. & Lythraceae & & & 4 & & & & & & 21 & & 1 & & & & & & & 2 & 1 \\
\hline 81 & $\begin{array}{l}\text { Lannea coromandelica } \\
\text { (Houtt.) Merr. }\end{array}$ & Anacardiaceae & & & 4 & & & & & & 3 & & & & & & & 1 & & & \\
\hline 82 & Lithocarpus braianensis A.Camus & Fagaceae & & & & & & & & 1 & 3 & & 2 & & & & & & & & 1 \\
\hline 83 & $\begin{array}{l}\text { Lithocarpus dealbatus (Hook. f. } \\
\text { \& Thomson ex Miq.) Rehder }\end{array}$ & Fagaceae & 1 & & & & 4 & 7 & 1 & 8 & 2 & 4 & 21 & 3 & 29 & 12 & 1 & 1 & 6 & 1 & 6 \\
\hline 84 & $\begin{array}{l}\text { Lithocarpus echinotholus (H.H. } \\
\text { Hu) Chun \& C.C. Huang }\end{array}$ & Fagaceae & & & & & & & & & 1 & & 1 & & & & 1 & & & & \\
\hline 85 & $\begin{array}{c}\text { Lithocarpus gigantophyllus } \\
\text { (Hickel \& A. Camus) A. Camus }\end{array}$ & Fagaceae & & & & & & & & & 6 & & 1 & & & & 2 & 1 & 2 & 2 & 3 \\
\hline 86 & $\begin{array}{l}\text { Lithocarpus truncatus (King ex } \\
\text { Hook. f.) Rehder \& E.H. Wilson }\end{array}$ & Fagaceae & 2 & 4 & 2 & & 1 & & 1 & & 3 & & & 1 & & & 1 & 12 & 21 & 15 & 25 \\
\hline 87 & $\begin{array}{c}\text { Litsea auriculata S.S. Chien \& } \\
\text { W.C. Cheng }\end{array}$ & Lauraceae & & & & & & & & & 2 & & & & & & & & & & \\
\hline 88 & Litsea balansae Lecomte & Lauraceae & 1 & 6 & 2 & & 1 & 12 & 4 & & & 5 & 1 & 4 & 1 & & 2 & 1 & & 8 & \\
\hline 89 & Litsea cubeba (Lour.) Pers. & Lauraceae & & & & 3 & & & & & & & & & & & & & & & \\
\hline 90 & Litsea elongata (Nees) Hook. f. & Lauraceae & & & & & & & & & & & & 3 & & & & & & & \\
\hline 91 & Litsea glutinosa (Lour.) C.B. Rob. & Lauraceae & 1 & 2 & & 6 & & & 9 & 1 & & 2 & 1 & 2 & 1 & & & 5 & 3 & 4 & 8 \\
\hline 92 & $\begin{array}{l}\text { Litsea lancifolia (Roxb. ex Nees) } \\
\text { Benth. \& Hook. f. ex Fern.-Vill. }\end{array}$ & Lauraceae & & & & & & & & & 1 & & & & & & & & & & 1 \\
\hline 93 & $\begin{array}{c}\text { Litsea martabanica } \\
\text { (Kurz) Hook. f. }\end{array}$ & Lauraceae & & & & & & & 2 & & & & 1 & & & & & & & & \\
\hline 94 & Litsea monopetala (Roxb.) Pers. & Lauraceae & & & & & & & & & & 3 & 3 & & & 1 & & & & & \\
\hline 95 & Litsea rotundifolia Hemsl. & Lauraceae & & & 1 & & & 6 & & & 1 & 1 & & & 6 & 5 & & & & & \\
\hline 96 & $\begin{array}{l}\text { Macaranga trichocarpa } \\
\text { (Zoll.) Müll.Arg. }\end{array}$ & Euphorbiaceae & 1 & 121 & 17 & 80 & & 1 & 124 & 1 & 1 & 2 & & & & & & 2 & 1 & & 5 \\
\hline 97 & $\begin{array}{l}\text { Magnolia braianensis } \\
\text { (Gagnep.) Figlar }\end{array}$ & Magnoliaceae & & & & & & & & & & 1 & & & & & & 5 & 9 & 6 & \\
\hline 98 & $\begin{array}{l}\text { Magnolia mediocris } \\
\text { (Dandy) Figlar }\end{array}$ & Magnoliaceae & 1 & & & & & & & 1 & 9 & & & & 1 & & & & & 2 & \\
\hline 99 & Mallotus barbatus Müll.Arg. & Euphorbiaceae & & 15 & & 15 & & & 2 & & & 8 & & & & & & 2 & 1 & 5 & 1 \\
\hline 100 & $\begin{array}{l}\text { Mallotus philippensis } \\
\text { (Lam.) Müll. Arg. }\end{array}$ & Euphorbiaceae & 23 & 9 & 11 & 6 & & & 8 & & 2 & & & & & & & 4 & & 1 & 3 \\
\hline 101 & Mangifera odorata Griff. & Anacardiaceae & & & & & & & & & & 3 & & & & 2 & & & & & \\
\hline 102 & $\begin{array}{l}\text { Melicope pteleifolia } \\
\text { (Champ. ex Benth.) T.G. Hartley }\end{array}$ & Rutaceae & 1 & & 4 & & & & & & 1 & & 6 & 2 & & 2 & 1 & & & & 1 \\
\hline
\end{tabular}


Table A2. Cont.

\begin{tabular}{|c|c|c|c|c|c|c|c|c|c|c|c|c|c|c|c|c|c|c|c|c|c|}
\hline \multirow{2}{*}{ No } & \multirow{2}{*}{ Species } & \multirow{2}{*}{ Family } & \multicolumn{6}{|c|}{ SF1 Plots } & \multicolumn{9}{|c|}{ SF2 Plots } & \multicolumn{4}{|c|}{ OGF Plots } \\
\hline & & & 1 & 2 & 3 & 4 & 5 & 6 & 1 & 2 & 3 & 4 & 5 & 6 & 7 & 8 & 9 & 1 & 2 & 3 & 4 \\
\hline 103 & $\begin{array}{l}\text { Memecylon scutellatum } \\
\text { (Lour.) Hook. \& Arn. }\end{array}$ & Melastomataceae & 1 & & & & & 1 & & 2 & 1 & 1 & & 1 & & & & 3 & 2 & & \\
\hline 104 & Millettia nigrescens Gagnep. & Fabaceae & & & & & & & & & 1 & & & & & & & & & & 1 \\
\hline 105 & Neolitsea ellipsoidea C.K. Allen & Lauraceae & 14 & 1 & 10 & 3 & & & 2 & & 3 & & 2 & & & 1 & & 16 & 16 & 6 & \\
\hline 106 & Ocotea lancifolia (Schott) Mez & Lauraceae & 23 & 3 & 10 & & & 3 & 1 & 4 & & 16 & 8 & 8 & 2 & 3 & 1 & 16 & 11 & 5 & 4 \\
\hline 107 & Ormosia sumatrana (Miq.) Prain & Fabaceae & & & & & & 3 & & & & & 1 & & 1 & & & & 3 & & \\
\hline 108 & Parinari anamensis Hance & Chrysobalanaceae & & & & & & & & & 4 & & & & & & & & & & \\
\hline 109 & $\begin{array}{c}\text { Peltophorum dasyrrhachis (Miq.) } \\
\text { Kurz }\end{array}$ & Fabaceae & & & 1 & & & & & & & & 1 & & & & & & & & \\
\hline 110 & Phoebe angustifolia Meisn. & Lauraceae & & & 12 & & 2 & 9 & & 20 & 27 & 101 & 9 & 14 & 12 & 10 & 2 & 13 & 2 & 7 & 12 \\
\hline 111 & Phoebe macrocarpa C.Y. Wu & Lauraceae & & & 4 & & & & & 8 & 3 & & & & & & & 1 & 1 & & \\
\hline 112 & Phyllanthus reticulatus Poir. & Phyllanthaceae & & & & & & & & & 2 & & & & & & & & & & \\
\hline 113 & $\begin{array}{l}\text { Polyalthia cerasoides (Roxb.) } \\
\text { Benth. \& Hook. f. ex Bedd. }\end{array}$ & Annonaceae & 3 & & 1 & & & & 3 & 3 & 1 & 1 & & & & & & 9 & 1 & 11 & 5 \\
\hline 114 & Premna mollissima Roth & Lamiaceae & & & 1 & & & & & & & & & & & & 1 & & & & \\
\hline 115 & Prunus arborea (Blume) Kalkman & Rosaceae & 1 & & 2 & & & & & & 2 & 1 & & & & & & 3 & 3 & & 1 \\
\hline 116 & $\begin{array}{c}\text { Prunus phaeosticta } \\
\text { (Hance) Maxim. }\end{array}$ & Rosaceae & & & & & & 11 & & & & & & & 18 & 7 & 2 & & & & \\
\hline 117 & Psydrax dicoccos Gaertn. & Rubiaceae & 1 & & & & & & & & & & & & & & & & & & \\
\hline 118 & $\begin{array}{c}\text { Pterospermum heterophyllum } \\
\text { Hance }\end{array}$ & Malvaceae & 2 & & & & & & & 3 & & & & & & & & 1 & & & \\
\hline 119 & Radermachera hainanensis Merr. & Bignoniaceae & 6 & & 1 & & & & & 1 & 1 & 2 & & & & & & 1 & 1 & & 1 \\
\hline 120 & Randia aculeata $\mathrm{L}$. & Rubiaceae & 1 & & 1 & 2 & & & & & & & & & & & & & & & \\
\hline 121 & Rhodoleia championii Hook. f. & Hamamelidaceae & & & & & & 5 & & & 4 & 1 & & & 44 & 5 & 75 & & 2 & & 2 \\
\hline 122 & Schefflera heptaphylla (L.) Frodin & Araliaceae & 1 & & 5 & & 1 & & & & & & 1 & 3 & 1 & 4 & 3 & 1 & 5 & 2 & 5 \\
\hline 123 & Schima wallichii (DC.) Korth. & Theaceae & & & & & & & & 20 & 4 & & 14 & 3 & & & & 1 & 11 & 16 & 13 \\
\hline 124 & Stereospermum annamense Dop & Bignoniaceae & & & 1 & & & & & & & & 1 & & & & & & & & \\
\hline 125 & $\begin{array}{c}\text { Styrax tonkinensis } \\
\text { (Pierre) Craib ex Hartwich }\end{array}$ & Styracaceae & & & 2 & & 5 & 24 & & 4 & 4 & 1 & 12 & 1 & 22 & 14 & 4 & & & & \\
\hline 126 & $\begin{array}{c}\text { Syzygium chunianum Merr. \& } \\
\text { L.M. Perry }\end{array}$ & Myrtaceae & & & 10 & 2 & & 16 & 3 & 45 & & & 3 & 3 & 4 & 3 & & & 15 & 8 & 18 \\
\hline 127 & Syzygium cumini (L.) Skeels & Myrtaceae & & & & & & 10 & & & & & & & & 3 & & & & & \\
\hline 128 & $\begin{array}{l}\text { Syzygium lanceolatum } \\
\text { (Lam.) Wight \& Arn. }\end{array}$ & Myrtaceae & 3 & & 2 & & 13 & 5 & 1 & 31 & 9 & 3 & 3 & 14 & 3 & 5 & 6 & 7 & 23 & 44 & 31 \\
\hline 129 & $\begin{array}{l}\text { Syzygium levinei (Merr.) } \\
\text { Merr. \& L.M. Perry }\end{array}$ & Myrtaceae & & & & & & & & & 8 & & & & & 3 & & & 9 & 8 & 5 \\
\hline
\end{tabular}


Table A2. Cont.

\begin{tabular}{|c|c|c|c|c|c|c|c|c|c|c|c|c|c|c|c|c|c|c|c|c|c|}
\hline \multirow{2}{*}{ No } & \multirow{2}{*}{ Species } & \multirow{2}{*}{ Family } & \multicolumn{6}{|c|}{ SF1 Plots } & \multicolumn{9}{|c|}{ SF2 Plots } & \multicolumn{4}{|c|}{ OGF Plots } \\
\hline & & & 1 & 2 & 3 & 4 & 5 & 6 & 1 & 2 & 3 & 4 & 5 & 6 & 7 & 8 & 9 & 1 & 2 & 3 & 4 \\
\hline 130 & $\begin{array}{l}\text { Terminalia bellirica } \\
\text { (Gaertn.) Roxb. }\end{array}$ & Combretaceae & & & & & & & & & & & 1 & & & & & & & & \\
\hline 131 & Toona sureni (Blume) Merr. & Meliaceae & & 1 & & & & & & & 1 & & & & & & & & & 2 & \\
\hline 132 & Trema orientalis (L.) Blume & Cannabaceae & 1 & 8 & & 64 & & & 20 & & & 1 & & & & & & 6 & & & \\
\hline 133 & $\begin{array}{c}\text { Trevesia palmata } \\
\text { (Roxb. ex Lindl.) Vis. }\end{array}$ & Araliaceae & 1 & & & & & & 1 & & & & & & & & & & & & \\
\hline 134 & Triadica cochinchinensis Lour. & Euphorbiaceae & & & & & & 10 & & 3 & 1 & & 2 & 2 & 4 & & & 2 & 6 & 5 & 6 \\
\hline 135 & Vitex pinnata $\mathrm{L}$ & Lamiaceae & & & & & & & & 1 & & & & 1 & & 1 & 1 & & & & 1 \\
\hline 136 & Walsura pinnata Hassk. & Meliaceae & 2 & 3 & 3 & & & & & 5 & 2 & 3 & 1 & & & 1 & & 10 & 20 & 7 & 12 \\
\hline 137 & $\begin{array}{l}\text { Wendlandia paniculata } \\
\text { (Roxb.) DC. }\end{array}$ & Rubiaceae & & & & & 6 & 29 & & & 9 & & 1 & 2 & 43 & 11 & 12 & & & 1 & \\
\hline 138 & Xylopia vielana Pierre & Annonaceae & & & 1 & & 2 & & & & & & 11 & 8 & 14 & 5 & & & & & 1 \\
\hline
\end{tabular}




\section{References}

1. Asner, G.P.; Knapp, D.E.; Broadbent, E.N.; Oliveira, P.J.; Keller, M.; Silva, J.N. Selective logging in the Brazilian Amazon. Science 2005, 310, 480-482. [CrossRef] [PubMed]

2. Wright, S.J. Tropical forests in a changing environment. Trends Ecol. Evol. 2005, 20, 553-560. [CrossRef] [PubMed]

3. Satdichanh, M.; Ma, H.; Yan, K.; Dossa, G.G.; Winowiecki, L.; Vågen, T.G.; Gassner, A.; Xu, J.; Harrison, R.D. Phylogenetic diversity correlated with above-ground biomass production during forest succession: Evidence from tropical forests in Southeast Asia. J. Ecol. 2019, 107, 1419-1432. [CrossRef]

4. Balmford, A. Extinction filters and current resilience: The significance of past selection pressures for conservation biology. Trends Ecol. Evol. 1996, 11, 193-196. [CrossRef]

5. Santos, B.A.; Arroyo-Rodríguez, V.; Moreno, C.E.; Tabarelli, M. Edge-related loss of tree phylogenetic diversity in the severely fragmented Brazilian Atlantic forest. PLoS ONE 2010, 5, e12625. [CrossRef]

6. Ouyang, S.; Xiang, W.; Wang, X.; Zeng, Y.; Lei, P.; Deng, X.; Peng, C. Significant effects of biodiversity on forest biomass during the succession of subtropical forest in south China. For. Ecol. Manag. 2016, 372, 291-302. [CrossRef]

7. Santo-Silva, E.E.; Santos, B.A.; Arroyo-Rodríguez, V.; Melo, F.P.; Faria, D.; Cazetta, E.; Mariano-Neto, E.; Hernández-Ruedas, M.A.; Tabarelli, M. Phylogenetic dimension of tree communities reveals high conservation value of disturbed tropical rain forests. Divers. Distrib. 2018, 24, 776-790. [CrossRef]

8. Lasky, J.R.; Uriarte, M.; Boukili, V.K.; Erickson, D.L.; John Kress, W.; Chazdon, R.L. The relationship between tree biodiversity and biomass dynamics changes with tropical forest succession. Ecol. Lett. 2014, 17, 1158-1167. [CrossRef] [PubMed]

9. Tucker, C.M.; Cadotte, M.W.; Carvalho, S.B.; Davies, T.J.; Ferrier, S.; Fritz, S.A.; Grenyer, R.; Helmus, M.R.; Jin, L.S.; Mooers, A.O. A guide to phylogenetic metrics for conservation, community ecology and macroecology. Biol. Rev. 2017, 92, 698-715. [CrossRef]

10. Gravel, D.; Bell, T.; Barbera, C.; Combe, M.; Pommier, T.; Mouquet, N. Phylogenetic constraints on ecosystem functioning. Nat. Commun. 2012, 3, 1-6. [CrossRef]

11. Cadotte, M.W. Phylogenetic diversity-ecosystem function relationships are insensitive to phylogenetic edge lengths. Funct. Ecol. 2015, 29, 718-723. [CrossRef]

12. Venail, P.; Gross, K.; Oakley, T.H.; Narwani, A.; Allan, E.; Flombaum, P.; Isbell, F.; Joshi, J.; Reich, P.B.; Tilman, D. Species richness, but not phylogenetic diversity, influences community biomass production and temporal stability in a re-examination of 16 grassland biodiversity studies. Funct. Ecol. 2015, 29, 615-626. [CrossRef]

13. Davies, T.J.; Urban, M.C.; Rayfield, B.; Cadotte, M.W.; Peres-Neto, P.R. Deconstructing the relationships between phylogenetic diversity and ecology: A case study on ecosystem functioning. Ecology 2016, 97, 2212-2222. [CrossRef] [PubMed]

14. Potter, K.M.; Woodall, C.M. Does biodiversity make a difference? Relationships between species richness, evolutionary diversity, and aboveground live tree biomass across US forests. For. Ecol. Manag. 2014, 321, 117-129. [CrossRef]

15. Rozendaal, D.M.; Chazdon, R.L. Demographic drivers of tree biomass change during secondary succession in northeastern Costa Rica. Ecol. Appl. 2015, 25, 506-516. [CrossRef]

16. Swenson, N.G.; Erickson, D.L.; Mi, X.; Bourg, N.A.; Forero-Montaña, J.; Ge, X.; Howe, R.; Lake, J.K.; Liu, X.; $\mathrm{Ma}, \mathrm{K}$. Phylogenetic and functional alpha and beta diversity in temperate and tropical tree communities. Ecology 2012, 93, S112-S125. [CrossRef]

17. Chazdon, R. Second Growth. (Intergovernmental Panel on Climate Change, Ed.), Climate Change 2013-The Physical Science Basis; University of Chicago Press: Chicago, IL, USA, 2014; Volume 53.

18. Giehl, E.L.; Jarenkow, J.A. Disturbance and stress gradients result in distinct taxonomic, functional and phylogenetic diversity patterns in a subtropical riparian tree community. J. Veg. Sci. 2015, 26, 889-901. [CrossRef]

19. Helmus, M.R.; Keller, W.; Paterson, M.J.; Yan, N.D.; Cannon, C.H.; Rusak, J.A. Communities contain closely related species during ecosystem disturbance. Ecol. Lett. 2010, 13, 162-174. [CrossRef] 
20. Burns, J.H.; Strauss, S.Y. More closely related species are more ecologically similar in an experimental test. Proc. Natl. Acad. Sci. USA 2011, 108, 5302-5307. [CrossRef]

21. Maire, V.; Gross, N.; Börger, L.; Proulx, R.; Wirth, C.D.S.; Pontes, L.; Soussana, J.F.; Louault, F. Habitat filtering and niche differentiation jointly explain species relative abundance within grassland communities along fertility and disturbance gradients. New Phytol. 2012, 196, 497-509.

22. Purschke, O.; Schmid, B.C.; Sykes, M.T.; Poschlod, P.; Michalski, S.G.; Durka, W.; Kühn, I.; Winter, M.; Prentice, H.C. Contrasting changes in taxonomic, phylogenetic and functional diversity during a long-term succession: Insights into assembly processes. J. Ecol. 2013, 101, 857-866. [CrossRef]

23. Mi, X.; Swenson, N.G.; Jia, Q.; Rao, M.; Feng, G.; Ren, H.; Bebber, D.P.; Ma, K. Stochastic assembly in a subtropical forest chronosequence: Evidence from contrasting changes of species, phylogenetic and functional dissimilarity over succession. Sci. Rep. 2016, 6, 32596. [CrossRef] [PubMed]

24. Zhu, Z.-X.; Nizamani, M.M.; Sahu, S.K.; Kunasingam, A.; Wang, H.F. Tree abundance, richness, and phylogenetic diversity along an elevation gradient in the tropical forest of Diaoluo Mountain in Hainan, China. Acta Oecol. 2019, 101, 103481. [CrossRef]

25. Monge-González, M.L.; Craven, D.; Krömer, T.; Castillo-Campos, G.; Hernández-Sánchez, A.; Guzmán-Jacob, V.; Guerrero-Ramírez, N.; Kreft, H. Response of tree diversity and community composition to forest use intensity along a tropical elevational gradient. Appl. Veg. Sci. 2020, 23, 69-79. [CrossRef]

26. Chave, J.; Réjou-Méchain, M.; Búrquez, A.; Chidumayo, E.; Colgan, M.S.; Delitti, W.B.; Duque, A.; Eid, T.; Fearnside, P.M.; Goodman, R.C. Improved allometric models to estimate the aboveground biomass of tropical trees. Glob. Chang. Biol. 2014, 20, 3177-3190. [CrossRef]

27. Con, T.V.; Thang, N.T.; Khiem, C.C.; Quy, T.H.; Lam, V.T.; van Do, T.; Sato, T. Relationship between aboveground biomass and measures of structure and species diversity in tropical forests of Vietnam. For. Ecol. Manag. 2013, 310, 213-218. [CrossRef]

28. Huy, B.; Kralicek, K.; Poudel, K.P.; Phuong, V.T.; Van Khoa, P.; Hung, N.D.; Temesgen, H. Allometric equations for estimating tree aboveground biomass in evergreen broadleaf forests of Viet Nam. For. Ecol. Manag. 2016, 382, 193-205. [CrossRef]

29. Nam, V.T.; van Kuijk, M.; Anten, N.P. Allometric equations for aboveground and belowground biomass estimations in an evergreen forest in Vietnam. PLoS ONE 2016, 11, e0156827. [CrossRef]

30. Do, T.V.; Sato, T.; Dai Hai, V.; Thang, N.T.; Binh, N.T.; Son, N.H.; Van Thuyet, D.; van Thang, H.; Hung, T.T.; van Con, T. Aboveground biomass and tree species diversity along altitudinal gradient in Central Highland, Vietnam. Trop. Ecol. 2017, 58, 95-104.

31. Kralicek, K.; Huy, B.; Poudel, K.P.; Temesgen, H.; Salas, C. Simultaneous estimation of above-and below-ground biomass in tropical forests of Viet Nam. For. Ecol. Manag. 2017, 390, 147-156. [CrossRef]

32. Baker, T.R.; Phillips, O.L.; Malhi, Y.; Almeida, S.; Arroyo, L.; Di Fiore, A.; Erwin, T.; Killeen, T.J.; Laurance, S.G.; Laurance, W.F. Variation in wood density determines spatial patterns in Amazonian forest biomass. Glob. Change Biol. 2004, 10, 545-562. [CrossRef]

33. Magurran, A.E. Ecological Diversity and Its Measurement; Princeton University Press: Princeton, NJ, USA, 1988.

34. Simpson, E.H. Measurement of diversity. Nature 1949, 163, 688. [CrossRef]

35. Heip, C.H.; Herman, P.M.; Soetaert, K. Indices of diversity and evenness. Oceanis 1998, 24, 61-88.

36. Fisher, R.A.; Corbet, A.S.; Williams, C.B. The relation between the number of species and the number of individuals in a random sample of an animal population. J. Anim. Ecol. 1943, 12, 42-58. [CrossRef]

37. Condit, R.; Hubbell, S.P.; Lafrankie, J.V.; Sukumar, R.; Manokaran, N.; Foster, R.B.; Ashton, P.S. Species-area and species-individual relationships for tropical trees: A comparison of three 50-ha plots. J. Ecol. 1996, 84, 549-562. [CrossRef]

38. Harper, D.A. Numerical Palaeobiology: Computer-Based Modelling and Analysis of Fossils and Their Distributions; John Wiley \& Sons Inc.: Chichester, UK, 1999.

39. Prodan, M. Messung der Waldbestande; Sauerlander's Verlag: Frankfurt/M, Germany, 1951; Volume 26.

40. Boyle, B.; Hopkins, N.; Lu, Z.; Garay, J.A.R.; Mozzherin, D.; Rees, T.; Matasci, N.; Narro, M.L.; Piel, W.H.; Mckay, S.J. The taxonomic name resolution service: An online tool for automated standardization of plant names. BMC Bioinform. 2013, 14, 16. [CrossRef] 
41. Gastauer, M.; Meira Neto, J.A.A. Updated angiosperm family tree for analyzing phylogenetic diversity and community structure. Acta Bot. Bras. 2017, 31, 191-198. [CrossRef]

42. Webb, C.O.; Ackerly, D.D.; McPeek, M.A.; Donoghue, M.J. Phylogenies and community ecology. Annu. Rev. Ecol. Syst. 2002, 33, 475-505. [CrossRef]

43. Webb, C.; Ackerly, D.; Kembel, S. Phylocom: Software for the Analysis of Phylogenetic Community Structure and Character Evolution, with Phylomatic and Ecoevolve, 2011. User's Manual, Version, 4. Available online: https://phylodiversity.net/phylocom/ (accessed on 5 October 2020).

44. Bell, C.D.; Soltis, D.E.; Soltis, P.S. The age and diversification of the angiosperms re-revisited. Am. J. Bot. 2010, 97, 1296-1303. [CrossRef]

45. Webb, C.O.; Ackerly, D.D.; Kembel, S.W. Phylocom: Software for the analysis of phylogenetic community structure and trait evolution. Bioinformatics 2008, 24, 2098-2100. [CrossRef]

46. Faith, D.P. Conservation evaluation and phylogenetic diversity. Biol. Conserv. 1992, 61, 1-10. [CrossRef]

47. Champely, S.; Chessel, D. Measuring biological diversity using Euclidean metrics. Environ. Ecol. Stat. 2002, 9, 167-177. [CrossRef]

48. Oksanen, J. Vegan: An Introduction to Ordination. Available online: http://cran.r-project.org/web/packages/ vegan/vignettes/introvegan (accessed on 5 October 2020).

49. Ouyang, S.; Xiang, W.; Wang, X.; Xiao, W.; Chen, L.; Li, S.; Sun, H.; Deng, X.; Forrester, D.I.; Zeng, L. Effects of stand age, richness and density on productivity in subtropical forests in China. J. Ecol. 2019, 107, 2266-2277. [CrossRef]

50. Poorter, L.; van der Sande, M.T.; Thompson, J.; Arets, E.J.; Alarcón, A.; Álvarez-Sánchez, J.; Ascarrunz, N.; Balvanera, P.; Barajas-Guzmán, G.; Boit, A. Diversity enhances carbon storage in tropical forests. Glob. Ecol. Biogeogr. 2015, 24, 1314-1328. [CrossRef]

51. Liang, J.; Crowther, T.W.; Picard, N.; Wiser, S.; Zhou, M.; Alberti, G.; Schulze, E.D.; McGuire, A.D.; Bozzato, F.; Pretzsch, H. Positive biodiversity-productivity relationship predominant in global forests. Science 2016, 354, aaf8957. [CrossRef] [PubMed]

52. Cadotte, M.W.; Dinnage, R.; Tilman, D. Phylogenetic diversity promotes ecosystem stability. Ecology 2012, 93, S223-S233.

53. Larkin, D.J.; Hipp, A.L.; Kattge, J.; Prescott, W.; Tonietto, R.K.; Jacobi, S.K.; Bowles, M.L. Phylogenetic measures of plant communities show long-term change and impacts of fire management in tallgrass prairie remnants. J. Appl. Ecol. 2015, 52, 1638-1648. [CrossRef]

54. Steudel, B.; Hallmann, C.; Lorenz, M.; Abrahamczyk, S.; Prinz, K.; Herrfurth, C.; Feussner, I.; Martini, J.W.; Kessler, M. Contrasting biodiversity-ecosystem functioning relationships in phylogenetic and functional diversity. New Phytol. 2016, 212, 409-420. [CrossRef]

55. Yuan, Z.; Wang, S.; Gazol, A.; Mellard, J.; Lin, F.; Ye, J.; Hao, Z.; Wang, X.; Loreau, M. Multiple metrics of diversity have different effects on temperate forest functioning over succession. Oecologia 2016, 182, 1175-1185. [CrossRef]

56. Dalmaso, C.A.; Marques, M.C.; Higuchi, P.; Zwiener, V.P.; Marques, R. Spatial and temporal structure of diversity and demographic dynamics along a successional gradient of tropical forests in southern Brazil. Ecol. Evol. 2020, 10, 3164-3177. [CrossRef]

57. Cadotte, M.W.; Davies, T.J.; Peres-Neto, P.R. Why phylogenies do not always predict ecological differences. Ecol. Monogr. 2017, 87. [CrossRef]

58. Marshall, A.R.; Willcock, S.; Platts, P.; Lovett, J.C.; Balmford, A.; Burgess, N.D.; Latham, J.; Munishi, P.; Salter, R.; Shirima, D. Measuring and modelling above-ground carbon and tree allometry along a tropical elevation gradient. Biol. Conserv. 2012, 154, 20-33. [CrossRef]

59. Dossa, G.G.; Paudel, E.; Fujinuma, J.; Yu, H.; Chutipong, W.; Zhang, Y.; Paz, S.; Harrison, R.D. Factors determining forest diversity and biomass on a tropical volcano, Mt. Rinjani, Lombok, Indonesia. PLoS ONE 2013, 8, e67720. [CrossRef] [PubMed] 
60. Girardin, C.A.; Farfan-Rios, W.; Garcia, K.; Feeley, K.J.; Jørgensen, P.M.; Murakami, A.A.; Cayola Pérez, L.; Seidel, R.; Paniagua, N.; Fuentes Claros, A.F. Spatial patterns of above-ground structure, biomass and composition in a network of six Andean elevation transects. Plant. Ecol. Divers. 2014, 7, 161-171. [CrossRef]

61. Culmsee, H.; Leuschner, C. Consistent patterns of elevational change in tree taxonomic and phylogenetic diversity across Malesian mountain forests. J. Biogeogr. 2013, 40, 1997-2010. [CrossRef]

Publisher's Note: MDPI stays neutral with regard to jurisdictional claims in published maps and institutional affiliations.

(C) 2020 by the authors. Licensee MDPI, Basel, Switzerland. This article is an open access article distributed under the terms and conditions of the Creative Commons Attribution (CC BY) license (http://creativecommons.org/licenses/by/4.0/). 